\title{
Pharmacological evaluation of new constituents of "Spice": synthetic cannabinoids based on indole, indazole, benzimidazole and carbazole scaffolds
}

\author{
Clara T. Schoeder ${ }^{1,3} \cdot$ Cornelius Hess $^{2} \cdot$ Burkhard Madea $^{2} \cdot$ Jens Meiler ${ }^{4} \cdot$ Christa E. Müller $^{1,3}$
}

Received: 16 March 2018 / Accepted: 5 April 2018 / Published online: 26 April 2018

(c) The Author(s) 2018

\begin{abstract}
Purpose In the present study we characterized a series of synthetic cannabinoids containing various heterocyclic scaffolds that had been identified as constituents of "Spice", a preparation sold on the illicit drug market. All compounds were further investigated as potential ligands of the orphan receptors GPR18 and GPR55 that interact with some cannabinoids.

Methods The compounds were studied in radioligand binding assays to determine their affinity for human cannabinoid $\mathrm{CB}_{1}$ and $\mathrm{CB}_{2}$ receptors expressed in $\mathrm{CHO}$ cells, and in cAMP accumulation assays to study their functionality.

Results Structure-activity relationships were analyzed. The most potent $\mathrm{CB}_{1}$ receptor agonist of the present series MDMBFUBINACA (12) $\left(K_{\mathrm{i}}=98.5 \mathrm{pM}\right)$ was docked into the human $\mathrm{CB}_{1}$ receptor structure, and a plausible binding mode was identified showing high similarity with that of the co-crystallized THC derivatives. MDMB-CHMCZCA (41) displayed a unique profile acting as a full agonist at the $\mathrm{CB}_{1}$ receptor subtype, but blocking the $\mathrm{CB}_{2}$ receptor completely. Only a few weakly potent antagonists of GPR18 and GPR55 were identified, and thus all compounds showed high CB receptor selectivity, mostly interacting with both subtypes, $\mathrm{CB}_{1}$ and $\mathrm{CB}_{2}$.
\end{abstract}

Conclusions These results will be useful to assess the compounds' toxicological risks and to guide legislation. Further studies on $\mathbf{4 1}$ are warranted.

Keywords Pharmacological evaluation of new synthetic cannabinoids $\cdot$ Affinities for $\mathrm{CB}_{1}$ and $\mathrm{CB}_{2}$ receptors $\cdot \beta$-Arrestin assay at GPR18 and GPR55 · cAMP accumulation assay $\cdot$ Benzimidazole and carbazole $\cdot$ Structure-activity relationships

Electronic supplementary material The online version of this article (https://doi.org/10.1007/s11419-018-0415-z) contains supplementary material, which is available to authorized users.

Christa E. Müller

christa.mueller@uni-bonn.de

1 PharmaCenter Bonn, Pharmaceutical Institute, Pharmaceutical Chemistry I, University of Bonn, An der Immenburg 4, 53121 Bonn, Germany

2 Institute of Forensic Medicine, Forensic Toxicology, University Hospital of Bonn, Stiftsplatz 12, 53111 Bonn, Germany

3 Research Training Group 1873, University of Bonn, 53127 Bonn, Germany

4 Departments of Chemistry and Pharmacology, Vanderbilt University, Stevenson Center, Station B 351822, Nashville, TN 37235, USA

\section{Introduction}

A challenging issue for forensic toxicologists and law makers is how to effectively respond to the constantly changing new psychoactive substances on the illicit drug market [1]. Among these, synthetic cannabinoids feature prominently [2, 3]. Between 2008, when so-called "Spice" products [4] containing synthetic cannabinoids began to appear on the drug market, and 2016, 169 new synthetic cannabinoids were confiscated and identified [2]. Most of them were discovered as powders, often in bulk amounts, while others were found in preparations of plant materials, e.g., minced herbs, onto which solutions of the cannabinoids had been sprayed [5]. These substances have been shown to bind to and in many cases activate cannabinoid (CB) receptors. $\mathrm{CB}$ receptors are divided into two subtypes, $\mathrm{CB}_{1}$ and $\mathrm{CB}_{2}$, which belong to the large family of rhodopsin-like class $\mathrm{A}$ G protein-coupled receptors (GPCRs) [6]. Both CB receptor subtypes are coupled to $\mathrm{G}_{\mathrm{i}}$ proteins including a reduction in 
intracellular cAMP levels. The main psychoactive effects of cannabinoids are mediated by the $\mathrm{CB}_{1}$ receptor, which is predominantly expressed in the central nervous system [7], while $\mathrm{CB}_{2}$ receptor expression in the brain is restricted to microglial cells $[8,9] . \mathrm{CB}_{2}$ receptors are highly expressed in the immune system, for example in tonsils and spleen [10, 11]. Activation of the $\mathrm{CB}_{2}$ receptor is considered as a new therapeutic option for the treatment of inflammatory diseases and pain $[12,13]$.

The plant-derived partial $\mathrm{CB}_{1}$ and $\mathrm{CB}_{2}$ receptor agonist $\Delta^{9}$-tetrahydrocannabinol $\left(\Delta^{9}\right.$-THC, 1, Fig. 1$)$ is used in therapy to target muscle spasms, nausea and cachexia [14]. The synthetic compound CP55,940 (2, Fig. 1) represents a potent full agonist at both receptor subtypes. $\mathrm{A} \mathrm{CB}_{1}$ receptor antagonist, rimonabant, had been approved for the treatment of obesity but was later withdrawn from the market due to side effects resulting in depression and an increased suicide rate [15].

The prevalence for the use of illegal psychoactive substances in Europe by 15-16 year-old teenagers was estimated in 2015 to be about 4\% [5]. Synthetic $\mathrm{CB}_{1}$ receptor agonists are abused as an alternative to natural marijuana due to their psychoactive and analgesic effects. For synthetic cannabinoids more and more severe side effects and intoxications are reported; they are predominantly neurologic symptoms, but acute organ toxicity has also been observed [16]. In the USA, the principle of enumeration is used to restrict newly discovered synthetic cannabinoids, and every single synthetic cannabinoid has to be individually listed by name in the US List of Schedule I drugs [17]. In Germany new synthetic cannabinoids are legally controlled since November 2016 when the "Neue-Psychoaktive-Stoffe-Gesetz" (NpSG, New Psychoactive Substances Act) was adopted in [18]. Similar regulations exist in Austria and Switzerland [19, 20]. All corresponding compounds, the chemical structures of which are represented by a general formula in the statute with known structure-activity relationships (SARs), were restricted. Newly discovered SARs of synthetic cannabinoids will, therefore, provide a basis for future amendments. However, in many cases, only limited information is available regarding the activity of new substances. Both the affinity of a drug for its receptor and its ability to produce an agonistic response are important features, and these should be determined according to a compound's chemical structure. For important classes of synthetic cannabinoids, at least four structural components, which have firstly been described by Huffman et al. and were later refined by the European Monitoring Centre for Drugs and Drug Addiction (EMCDDA), are of importance (see Fig. 2 [3]): (1) a heterocyclic core consisting of indole or indazole with different substitutions; (2) a linker, e.g., an ester, amide or ketone; (3) a bulky lipophilic residue $\left(\mathrm{R}^{1}\right)$, e.g., a heterocyclic or aryl substituent, but in newer synthetic cannabinoids a lipophilic amino acid can also be found; and (4) a residue $\left(\mathrm{R}^{2}\right)$ which is a hydrophobic "side chain" attached to the nitrogen atom of the indole or the indazole ring system [21, 22]. The compound JWH-018 (3, see Fig. 1), a potent $\mathrm{CB}_{1}$ and $\mathrm{CB}_{2}$ receptor agonist, displays the basic features of this compound class and was one of the first synthetic cannabinoids identified in herbal blends for abuse [23, 24]. The common features of known synthetic cannabinoids are depicted in Fig. 2.

In a previous study [25], we had determined the pharmacological properties of 48 synthetic cannabinoids collected by the Institute of Forensic Medicine of the University of Bonn. In the present study, we investigated the affinities and functional properties of a new series of 42 synthetic cannabinoids, 16 of which have not been reported as cannabinoid receptor ligands before. The investigated set of compounds comprises four different core structures. The first three groups (A, B, C, see Table 1) represent differently substituted indoles and indazoles, which are structurally derived from the synthetic cannabinoids previously introduced by Huffman et al. and are widely distributed in illicitly sold "Spice"

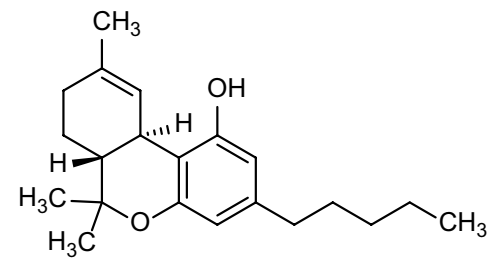

$1 \Delta^{9}-\mathrm{THC}$

$\mathrm{CB}_{1}: K_{i}=5.05-80.3 \mathrm{nM}[12]$

$\mathrm{CB}_{2}: K_{i}=3.13-75.3 \mathrm{nM}[12]$

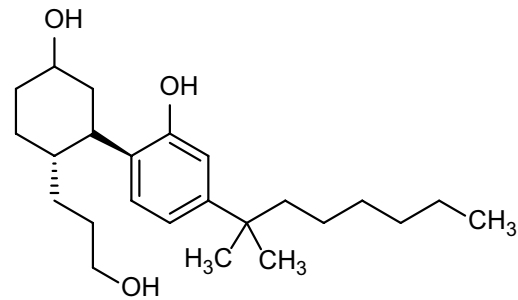

2 CP55,940

$\mathrm{CB}_{1}: K_{i}=0.5-5.0 \mathrm{nM}[12]$

$\mathrm{CB}_{2}: K_{i}=0.69-2.8 \mathrm{nM}[12]$

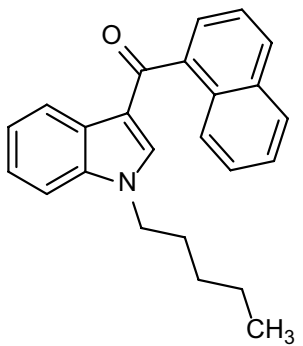

$3 \mathrm{JWH}-018$

$\mathrm{CB}_{1}: K_{i}=9 \mathrm{nM}[22]$

$\mathrm{CB}_{2}: K_{i}=2.9 \mathrm{nM}[22]$

Fig. 1 Standard cannabinoid $\mathrm{CB}_{1} / \mathrm{CB}_{2}$ receptor agonists $[12,22]$ 
Fig. 2 Common structural features of synthetic cannabinoids. The figure was adopted from the European Monitoring Centre for Drugs and Drug Addiction (EMCDDA) [3] and modified

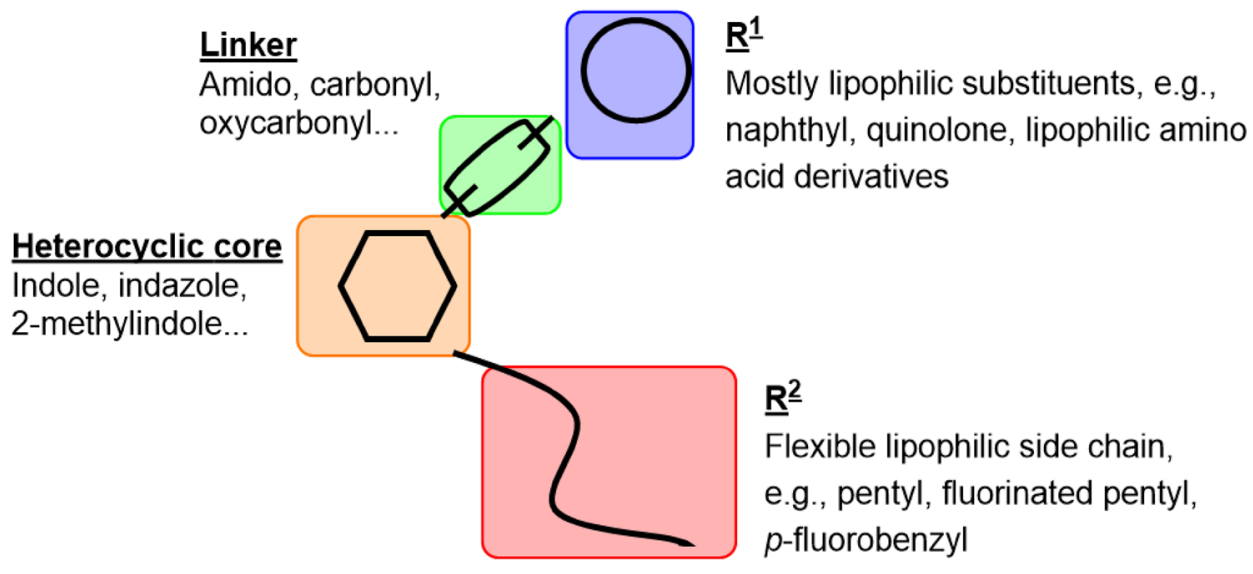

products. In the current study we investigated compounds with L-valinamide $(\mathrm{AB}) / \mathrm{L}$-tert-leucinamide (ADB or MAB), methyl-3,3-dimethylbutanoate (MDMB), methyl3-methylbutanoate (MMB), and 2-methyl-2-phenylpropyl (cumyl) moieties as substituents in the $\mathrm{R}^{1}$ position. Further classes of compounds consist of carbazoles (E), substituted in position 3, and benzimidazole derivatives $(\mathrm{F})$.

Radioligand binding and cAMP functional studies on $\mathrm{CB}_{1}$ and $\mathrm{CB}_{2}$ receptors were complemented by $\mathrm{CB}_{1}$ receptor modeling and docking of the most potent $\mathrm{CB}_{1}$ receptor agonist of the present series to predict its interactions. We further tested all compounds for their ability to activate or block the two orphan GPCRs GPR18 and GPR55, both of which are known to interact with cannabinoids [26-29]. We discuss SARs of the newly investigated compounds, integrating previously reported data, thereby providing a comprehensive analysis, which will help to predict properties of novel derivatives.

\section{Methods}

\section{Compounds}

All compounds except for MDMB-CHMCZCA (41) were obtained from Cayman Chemical (Ann Arbor, MI, USA). According to the manufacturer, the purity of all compounds was declared to be $>95 \%$ as determined by liquid chromatography-tandem mass spectrometry (LC-MS/ MS). MDMB-CHMCZCA (41) was purchased from www. brc-finechemicals.com. We confirmed the purity of all compounds in our laboratories by liquid chromatography-ultraviolet-mass spectrometry (LC-UV-MS) measurements and found it to be generally $\geq 96 \%$, except for MDMB-FUBINACA $(\mathbf{1 2}, 93 \%)$ and $\mathrm{Cl}-2201(\mathbf{3 7}, 86 \%)$.

\section{Radioligand binding assays}

Radioligand binding assays were performed as described previously [25]. Membrane preparations of Chinese hamster ovary $(\mathrm{CHO})$ cells overexpressing the human $\mathrm{CB}$ receptor subtype $\mathrm{CB}_{1}$ or $\mathrm{CB}_{2}$ were incubated in the presence of the test compound and the radioligand $\left[{ }^{3} \mathrm{H}\right] \mathrm{CP} 55,940(0.1 \mathrm{nM}$, see Fig. 1) (Perkin-Elmer Life Sciences, Rodgau-Jügesheim, Germany), for $2 \mathrm{~h}$. Bound and unbound radioligand were separated by rapid filtration through glass fiber GF/C-filters (Perkin-Elmer, Boston, MA, USA), using a Brandel 96-well Harvester (Brandel, Gaithersburg, MD, USA). Radioactivity on the filters was determined by liquid scintillation counting. Three separate experiments were performed, each in duplicates.

\section{CAMP accumulation assays}

cAMP accumulation assays were performed also as previously described [25]. Briefly, CHO cells stably expressing the respective human $\mathrm{CB}$ receptor subtype $\mathrm{CB}_{1}$ or $\mathrm{CB}_{2}$ were seeded overnight. Then the phosphodiesterase inhibitor Ro-20-1724 [4-(3-butoxy-4-methoxyphenyl) methyl-2-imidazolidone; Sigma-Aldrich, St. Louis, MO, USA], and subsequently the test compound (10-1 $\mu \mathrm{M})$ and forskolin (10 $\mu \mathrm{M}$, Sigma-Aldrich) were added. After incubation for $15 \mathrm{~min}$ the buffer was removed, and the cells were lyzed. The amount of cAMP was determined in a radioligand binding assay by incubating $50 \mu \mathrm{L}$ of the cell lysate with $3 \mathrm{nM}\left[{ }^{3} \mathrm{H}\right] \mathrm{cAMP}$ in the presence of protein preparations from bovine adrenal glands (cAMP binding protein) [30]. Bound and unbound radioligand were separated by rapid filtration through $\mathrm{GF} / \mathrm{B}$ filters, and radioactivity was determined by liquid scintillation counting. To test for antagonistic activity, test compounds were added to Hank's buffered salt solution (HBSS) containing 10\% 
Table 1 Affinities of the investigated indoles, indazoles and carbazoles at the cannabinoid $\mathrm{CB}_{1}$ and $\mathrm{CB}_{2}$ receptors determined in radioligand binding assays

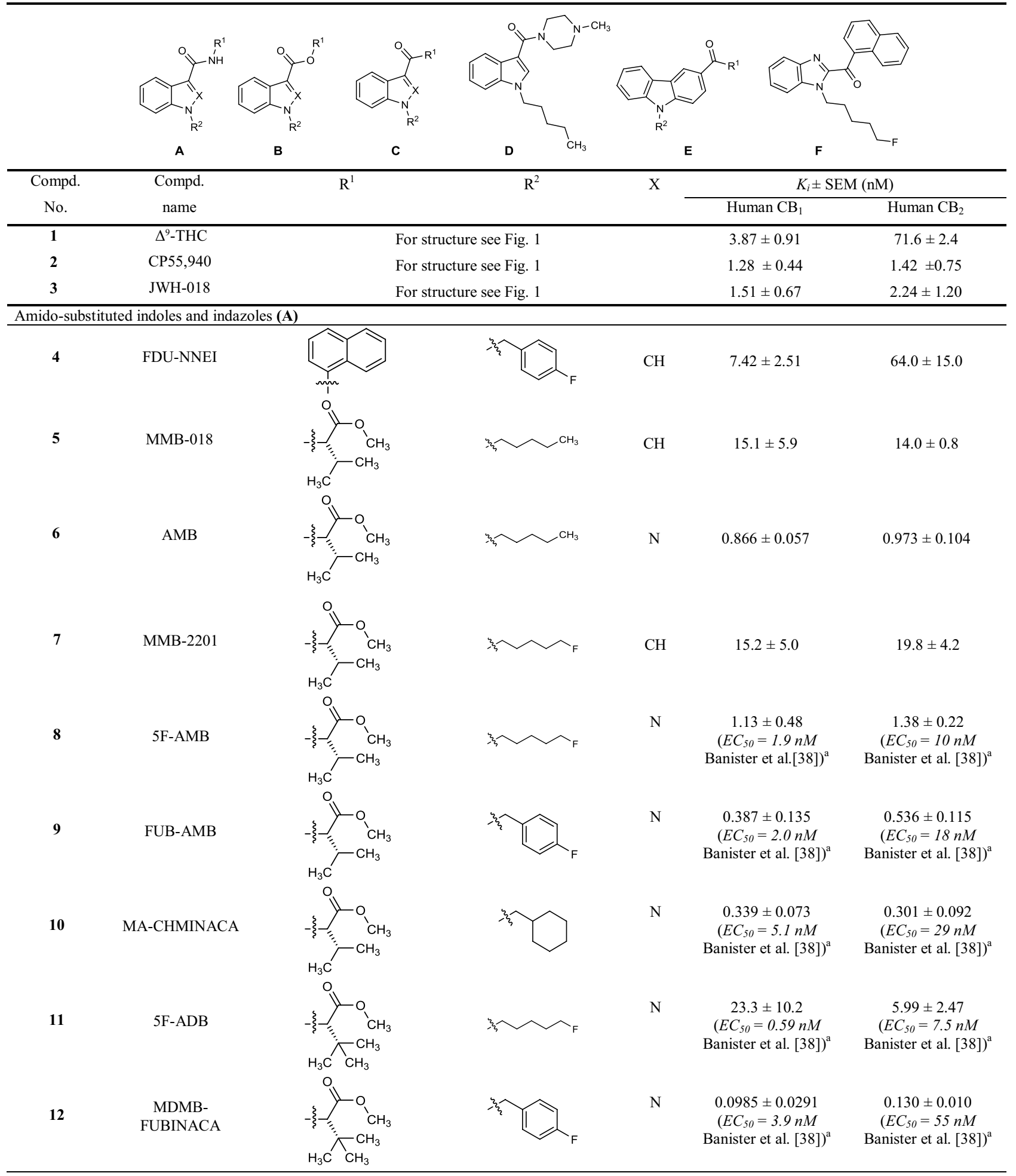


Table 1 (continued)

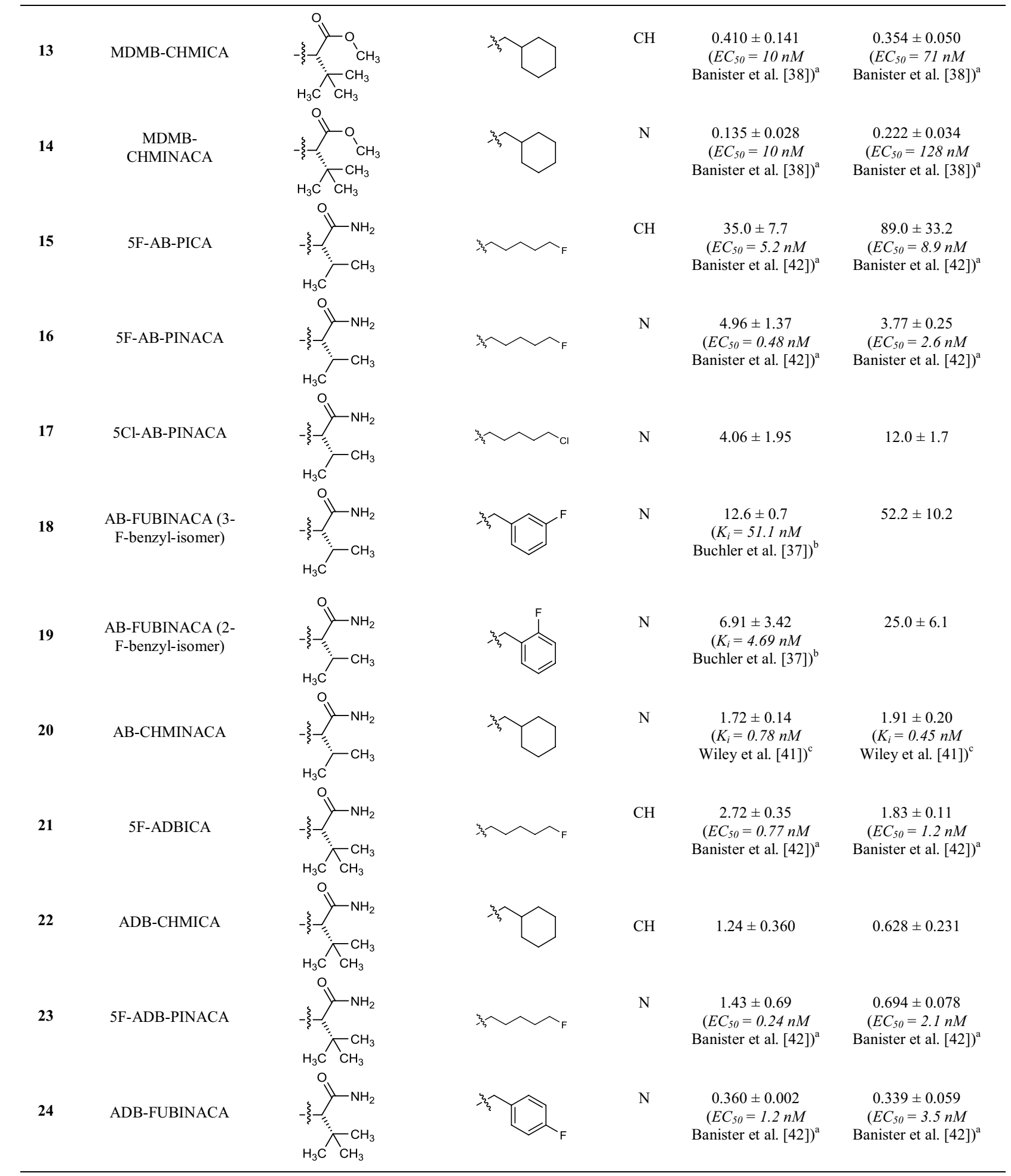


Table 1 (continued)

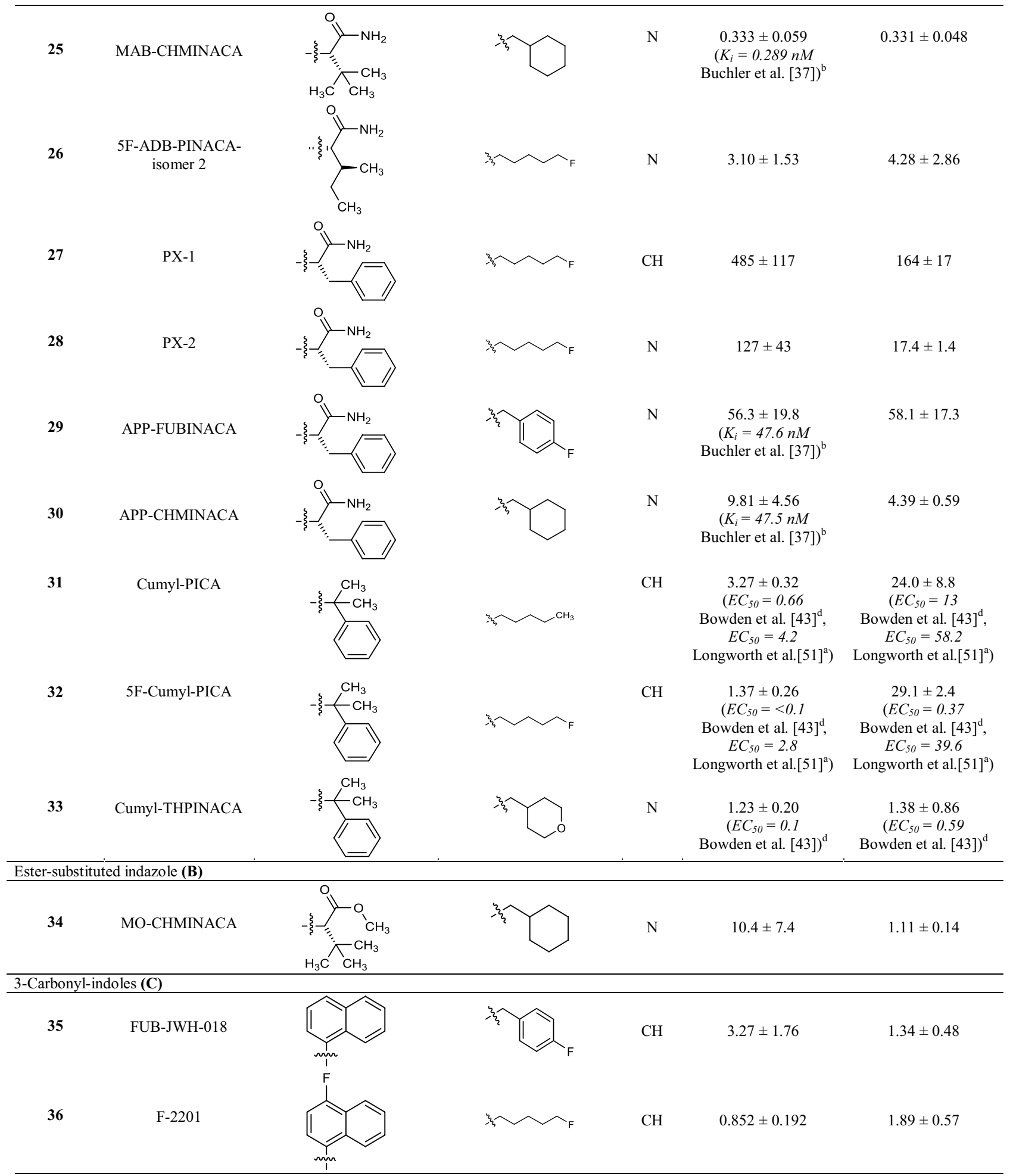


Table 1 (continued)

\begin{tabular}{llll}
\hline 37 \\
39
\end{tabular}

${ }^{a}$ Fluorometric imaging plate reader membrane potential assay system from Molecular Devices (Sunnyvale, CA, USA)

${ }^{\mathrm{b}}$ Radioligand binding study versus $0.5 \mathrm{nM}\left[{ }^{3} \mathrm{H}\right] \mathrm{CP} 55,940$

${ }^{\mathrm{c}}$ Radioligand binding study versus $\left.0.62 \mathrm{nM} \mathrm{[}{ }^{3} \mathrm{H}\right] \mathrm{CP} 55,940$

${ }^{\mathrm{d}}$ Homogenous time resolved fluorescence-based cAMP accumulation

dimethyl sulfoxide (DMSO), 10 min after the application of Ro-20-1724, and the mixture was incubated for $20 \mathrm{~min}$ at $37{ }^{\circ} \mathrm{C}$. Then, the $\mathrm{CB}$ agonist $\mathrm{CP} 55,940$ was added at a concentration of $0.03 \mu \mathrm{M}$, and cAMP determination was carried out as described above [25].

\section{$\beta$-Arrestin assays}

$\beta$-Arrestin assays were performed in recombinant $\mathrm{CHO}$ cells expressing either the human GPR18 or the human GPR55 as described before using the $\beta$-galactosidase enzyme fragment complementation technology ( $\beta$-arrestin PathHunter ${ }^{\mathrm{TM}}$ assay; DiscoverX, Fremont, CA, USA) [25].

\section{Data analysis}

Data were analyzed using GraphPad Prism Version 4.026.1, (GraphPad Software, San Diego, CA, USA).

\section{Molecular docking}

Molecular docking studies were carried out with the software package Rosetta (www.RosettaCommons.org) using the 2017.08.59291 build [31, 32]. As templates the X-ray structures 5XRA and 5XR8 were employed [33]; fusion proteins and ligands were deleted and a conformer of MDMBFUBINACA (12) was manually positioned in an initial model using the PyMOL Molecular Graphics System, Version 1.7.4.5 (Schrödinger, Inc., New York, NY, USA). A conformer library of MDMB-FUBINACA (12) was calculated using the BCL Conformer:Generator [34]. Docking procedure and scripts for data processing are described in supplementary material. Docking scores were calculated using the Rosetta InterfaceAnalyzer. The best scoring models were clustered into a set of plausible binding poses. Results were compared to the pose of THC-like agonists in the template crystal structures 5XRA and 5XR8 and displayed using UCSF Chimera [35].

\section{Results and discussion}

\section{Cannabinoid $\mathrm{CB}_{1}$ and $\mathrm{CB}_{2}$ receptor affinities}

In the present study, $\mathrm{CB}_{1}$ and $\mathrm{CB}_{2}$ receptor affinities of a new series of synthetic cannabinoids were determined in radioligand binding studies, which provide an ideal basis for the analysis of SARs (Table 1). The investigated compounds comprise indole, indazole, benzimidazole and carbazole 
derivatives. For some of the compounds, $\mathrm{EC}_{50}$ values had previously been determined by functional assays; however, functional data are highly dependent on the expression level of the receptors or "receptor reserve", while $K_{\mathrm{i}}$ values obtained in binding studies are largely independent of the employed cellular background [36].

The present set of compounds includes amino acid derivatives. These types of compounds were originally described in a patent and claimed as potential pain therapeutics [37]. In all cases, an alkyl or heteroaryl residue was introduced as $\mathrm{R}^{2}$, and the amino acid was coupled to an amino group in the $\mathrm{R}^{1}$ position (see Table 1; Fig. 2) [37]. The presented compounds feature a pentyl or 5-fluoropentyl side chain in position $\mathrm{R}^{2}$ (for Table 1; Fig. 2). MMB-018 (5), an indole derivative substituted with a valine methyl ester, showed affinity in the low nanomolar range with a $K_{\mathrm{i}}$ value of $15.1 \mathrm{nM}$ at the $\mathrm{CB}_{1}$ receptor and an almost identical $K_{\mathrm{i}}$ value of $14.0 \mathrm{nM}$ at the $\mathrm{CB}_{2}$ receptor. The corresponding indazole AMB (6) was more potent displaying subnanomolar affinity for both CB receptor subtypes $\left(\mathrm{CB}_{1} K_{\mathrm{i}}=0.866 \mathrm{nM} ; \mathrm{CB}_{2}\right.$ $K_{\mathrm{i}}=0.973 \mathrm{nM}$ ), indicating the superiority of the indazole core. The 5-fluoropentyl derivatives MMB-2201 (7) and 5F-AMB (8) were similarly as potent as their pentyl analogues MMB-018 (5) and AMB (6), respectively, showing that the terminal fluorination of the pentyl side chain gives almost no effect. Compounds with a $p$-fluorobenzyl residue or a bioisosteric cyclohexylmethyl residue showed increased affinities in the subnanomolar range in the indazole series (FUB-AMB (9), $\mathrm{CB}_{1} K_{\mathrm{i}}=0.387 \mathrm{nM}$, and MA-CHMINACA (10), $\mathrm{CB}_{1} K_{\mathrm{i}}=0.339 \mathrm{nM}$ ) and were about equipotent at the $\mathrm{CB}_{2}$ receptor. Banister et al. [38] had already investigated these compounds and also 5F-AMB (8) in a fluorescencebased membrane potential assay and determined potencies in the nanomolar range $\left(\mathrm{EC}_{50}\right.$ values ranging from 1.9 to $71 \mathrm{nM}$ ) in that assay, while our radioligand binding assay revealed higher affinities.

The valine methyl ester was replaced by a tert-leucine methyl ester in four of the investigated compounds: 5F-ADB (11), MDMB-FUBINACA (12), MDMB-CHMICA (13) and MDMB-CHMINACA (14), substituted with each 5-fluoropentyl (11), $p$-fluorobenzyl (12) and cyclohexylmethyl residue $(\mathbf{1 3 , 1 4})$ for $\mathrm{R}^{2}$, respectively. MDMB-FUBINACA (12) was the most potent compound of the entire set of investigated compounds with a $K_{\mathrm{i}}$ value of $0.0985 \mathrm{nM}$ at the $\mathrm{CB}_{1}$ receptor and $0.130 \mathrm{nM}$ at the $\mathrm{CB}_{2}$ receptor. Banister et al. [38] had reported $\mathrm{EC}_{50}$ values of $3.9 \mathrm{nM}$ at $\mathrm{CB}_{1}$ and of $55 \mathrm{nM}$ at $\mathrm{CB}_{2}$ receptors determined in a fluorescence-based membrane potential assay for this compound [38]. MDMBFUBINACA had caused the highest hypothermal response which the authors had ever observed in rats [38]. These results showed once more that functional assays often do not correctly predict compounds' affinities. MDMB-CHMICA (13), which also showed subnanomolar affinities for $\mathrm{CB}_{1}$ and $\mathrm{CB}_{2}$ receptors, was previously found to be involved in fatal intoxications, and it was concluded that the compound could cause multiple organ failure with lethal outcome in combination with alcohol $[39,40]$. The corresponding indazole MDMB-CHMINACA (14) again showed even slightly higher affinities for both receptors.

Next, compounds with a valinamide substitution $\left(\mathrm{R}^{1}\right)$ were studied. These were somewhat less potent than the valine methyl esters [compare 5F-AB-PICA (15)/MMB2201 (7); AB-CHMINACA (20)/MA-CHMINACA (10); and 5F-AB-PINACA (16)/5F-AMB (8)]. 5F-AB-PICA (15), a 5F-pentyl-indole derivative, displayed affinities of $35.0 \mathrm{nM}$ and $89.0 \mathrm{nM}$ for $\mathrm{CB}_{1}$ and $\mathrm{CB}_{2}$ receptors, respectively, while the corresponding indazole 5F-AB-PINACA (16) was more potent displaying affinities in the low nanomolar range. We further investigated the 5Cl-pentyl derivative 5Cl-AB-PINACA (17), which showed comparable $K_{\mathrm{i}}$ values to 5F-ABPINACA (16) at $4.06 \mathrm{nM}$ for $\mathrm{CB}_{1}$ and $12.0 \mathrm{nM}$ for $\mathrm{CB}_{2}$. The $m$-fluorobenzyl and the $o$-fluorobenzyl derivatives (18 and 19) showed similar affinities at the $C_{1}$ receptor, as also previously reported by Buchler et al. [37], with $K_{\mathrm{i}}$ values in the nanomolar range, and somewhat lower affinity for the $\mathrm{CB}_{2}$ receptor. AB-CHMINACA (20) displayed low nanomolar $\mathrm{CB}_{1}$ and $\mathrm{CB}_{2}$ affinity in agreement with previous results by Wiley et al. [41].

5F-ADB-PINACA isomer 2 (26) contains a structural isomer of isoleucinamide with a different side chain. This modification resulted in a slight decrease in affinities to $\mathrm{CB}_{1}$ and $\mathrm{CB}_{2}$ as compared to 5F-ADB-PINACA (23), the corresponding tert-leucinamide. Furthermore, tert-leucinamides, have been investigated which contain a tert-butyl group. The 5-fluoropentyl-substituted indole derivative 5F-ADBICA (21) showed nanomolar affinities with a $K_{\mathrm{i}}$ of $2.72 \mathrm{nM}$ at $\mathrm{CB}_{1}$ and $1.83 \mathrm{nM}$ at $\mathrm{CB}_{2}$ receptors. This was in agreement with data published by Banister et al. [42], who had reported similar $\mathrm{EC}_{50}$ values. We found the corresponding indazole derivative 23 to be slightly more potent with $K_{\mathrm{i}}$ values at $1.43 \mathrm{nM}$ for $\mathrm{CB}_{1}$ and $0.694 \mathrm{nM}$ for $\mathrm{CB}_{2}$. Banister et al. had determined a higher potency at $\mathrm{CB}_{1}$ with an $\mathrm{EC}_{50}$ value of $0.24 \mathrm{nM}$ in their membrane potential assay, but a slightly higher $\mathrm{EC}_{50}$ value at $\mathrm{CB}_{2}(2.1 \mathrm{nM})$. The $p$-fluorobenzyl-substituted indazole ADB-FUBINACA (24) showed even lower $K_{\mathrm{i}}$ values of $0.360 \mathrm{nM}$ for $\mathrm{CB}_{1}$ and $0.339 \mathrm{nM}$ for $\mathrm{CB}_{2}$. The indole ADB-CHMICA (22) was substituted in the $\mathrm{R}^{2}$ position with a cyclohexylmethyl residue and showed a $K_{\mathrm{i}}$ value of $1.24 \mathrm{nM}$ for the $\mathrm{CB}_{1}$ and $0.628 \mathrm{nM}$ for the $\mathrm{CB}_{2}$ receptor. The corresponding indazole MAB-CHMINACA (25), which had been introduced by Buchler et al. [37], was even more potent with a $K_{\mathrm{i}}$ value of $0.333 \mathrm{nM}$ for $\mathrm{CB}_{1}$ and $0.331 \mathrm{nM}$ for $\mathrm{CB}_{2}$, which fits well with data reported by Buchler et al. for $\mathrm{CB}_{1}$ (no data for $\mathrm{CB}_{2}$ had been published by them).

PX-1 (27) and PX-2 (28) are phenylalaninamide derivatives, PX-1 (27) with an indole core and PX-2 (28) with an 
indazole core structure. PX-2 (28) showed a $K_{\mathrm{i}}$ value for the $\mathrm{CB}_{1}$ receptor of $127 \mathrm{nM}$ and was thus significantly less potent than the corresponding tert-leucinamide derivative 5F-ADB-PINACA (23). The $K_{\mathrm{i}}$ value at $\mathrm{CB}_{2}(17.4 \mathrm{nM})$ was also higher than the $K_{\mathrm{i}}$ value of $0.694 \mathrm{nM}$ determined for 5F-ADB-PINACA (23). Indole derivative PX-1 (27) displayed a $K_{\mathrm{i}}$ value of $485 \mathrm{nM}$ for $\mathrm{CB}_{1}$, corresponding to a fourfold decrease in affinity as compared to the indazole PX-2 (28). The $K_{\mathrm{i}}$ value at $\mathrm{CB}_{2}(164 \mathrm{nM})$ was about tenfold higher. This confirms that the indazole ring system generally leads to a higher affinity as compared to the indole core structure.

APP-FUBINACA (29) and APP-CHMINACA (30) had been introduced by Buchler et al. [37]. Both are indazoles varying in position $\mathrm{R}^{2}$. The $p$-fluorobenzyl derivative APPFUBINACA (29) showed potencies for both CB receptor subtypes of around $50 \mathrm{nM}$, while the corresponding cyclohexylmethyl derivative APP-CHMINACA (30) was more potent displaying $K_{\mathrm{i}}$ values of $9.81 \mathrm{nM}$ for $\mathrm{CB}_{1}$ and $4.39 \mathrm{nM}$ for $\mathrm{CB}_{2}$.

Instead of an amino acid residue, the $\mathrm{R}^{1}$ position has also been substituted with a cumyl moiety. These types of compounds were first described by Bowden and Williamson [43] and it has recently been found in illicit drug material. For all three investigated cumyl derivatives (31-33), we could demonstrate affinities in the low nanomolar range for the $\mathrm{CB}_{1}$ receptor. Bowden and Williamson had reported subnanomolar $\mathrm{EC}_{50}$ values in their functional assays using a homogeneous time-resolved fluorescence (HTRF)-based cAMP assay [43]. The indole derivatives Cumyl-PICA (31) and 5F-Cumyl-PICA (32) in our hands displayed potencies of around $25 \mathrm{nM}$ for the $\mathrm{CB}_{2}$ receptor, while Cumyl-THPINACA (33) bearing a 4-tetrahydropyranylmethyl moiety (for $\mathrm{R}^{2}$ ) was more potent with a $K_{\mathrm{i}}$ value of $1.38 \mathrm{nM}$ at the $\mathrm{CB}_{2}$ receptor, which was similar to its $K_{\mathrm{i}}$ value at the $\mathrm{CB}_{1}$ receptor.

The investigated series of compounds contained one member with a 3-oxycarbonyl linker: MO-CHMINACA (34), an indazole with a cyclohexylmethyl residue for $\mathrm{R}^{2}$ and a methoxycarbonyl-tert-leucine for $\mathrm{R}^{1}$. It displayed a $K_{\mathrm{i}}$ value of $10.4 \mathrm{nM}$ at $\mathrm{CB}_{1}$ and $1.11 \mathrm{nM}$ at $\mathrm{CB}_{2}$ receptors. The only other cyclohexylmethyl-substituted compound investigated by us was BB-22 (see our previous study [25]), which exhibited a $K_{\mathrm{i}}$ value of $0.217 \mathrm{nM}$ for $\mathrm{CB}_{1}$ receptor; however it was substituted with a quinolone for $\mathrm{R}^{1}$ and contained an indole core.

Three 3-carbonylindoles (35-37) were studied. FUBJWH-018 (35), substituted with a naphthyl residue for $\mathrm{R}^{1}$ and possessing a $p$-fluorobenzyl residue for $\mathrm{R}^{2}$ displayed similarly high nanomolar affinities like the previously studied naphthoyl indazoles THJ018 and THJ2201 [25]. MAM-2201 and EAM-2201, which were substituted with methyl or ethyl in the 4-position of the naphthoyl residue, had shown subnanomolar affinities [25]. Here we report F-2201 (36) and Cl-2201 (37), the respective 4-fluoroand 4-chloro derivatives. Both displayed high affinities at 1-2 $\mathrm{nM}$ for both $\mathrm{CB}_{1}$ and $\mathrm{CB}_{2}$ receptors. The previously described alkyl-substituted naphthoyl derivatives had shown similar potencies (compare MAM-2201 and EAM-2201) [25]. The substitutions can be ranked in the following order of potency at $\mathrm{CB}_{1}$ : ethyl $>$ fluoro $>$ chloro $>$ methyl, while for $\mathrm{CB}_{2}$ it was: ethyl $>$ methyl $>$ fluoro $\approx$ chloro.

The indole derivative mepirapim (38) belongs to the 3-amido-substituted derivatives, featuring a 4-methylpiperazinyl residue for $\mathrm{R}^{1}$. Mepirapim (38) was originally identified by Uchiyama et al. [44] and has been found in "Spice" preparations. We determined an affinity of $2650 \mathrm{nM}$ for the $\mathrm{CB}_{1}$ receptor and $1850 \mathrm{nM}$ for the $\mathrm{CB}_{2}$ receptor. Therefore, it can be regarded as a rather weak $\mathrm{CB}$ receptor ligand.

We further investigated three structurally dissimilar compounds, 39-41, which contain a carbazole core substituted in position 3 with residues typically observed in position $\mathrm{R}^{1}$ of indazole- and indole-based compounds. EG-018 (39) and EG-2201 (40) feature a carbonyl linker connected to a naphthyl residue, whereas MDMB-CHMCZCA (41) is substituted with a methoxycarbonyl-tertleucine residue through an amide linker. EG-018 (39) displayed low nanomolar affinities with $K_{\mathrm{i}}$ values of $7.17 \mathrm{nM}$ for $\mathrm{CB}_{1}$ and of $2.27 \mathrm{nM}$ for the $\mathrm{CB}_{2}$ receptor. EG-018 (39) can be compared to JWH-018 (3), which showed similar affinities. EG-2201 (40) was less potent at $\mathrm{CB}_{1}$ with a $K_{\mathrm{i}}$ value of $22.4 \mathrm{nM}$, but only slightly more potent at $\mathrm{CB}_{2}\left(K_{\mathrm{i}}=4.36 \mathrm{nM}\right)$. MDMB-CHMCZCA (41) also displayed affinities in the low nanomolar range. The observed switch from indoles and indazoles to carbazoles can be interpreted as a reaction to the NpSG legislation and similar regulations in other countries that restricted the whole class of indoles and indazoles based on the known SARs. Recently, the synthetic cannabinoid Cumyl-PEGACLONE was identified as one of the first cannabimimetic compounds to circumvent these regulations; it consists of a $\gamma$-carboline, another new scaffold for cannabinoid receptor agonists [45]. Carbazoles (39-41) represent a further new scaffold which circumvents restrictions applied by many, especially European, countries by simply exchanging the well-established bicyclic core structures of indole or indazole for a tricyclic carbazole ring system.

We further investigated the benzimidazole derivative FUBIMINA (42), which had previously been described by Wiley et al. [41], and determined a $K_{\mathrm{i}}$ value of $502 \mathrm{nM}$ at the $\mathrm{CB}_{1}$ receptor, which is in the same range as the reported $K_{\mathrm{i}}$ value of $296 \mathrm{nM}$, and a $K_{\mathrm{i}}$ value of $99.0 \mathrm{nM}$ for the $\mathrm{CB}_{2}$ receptor, which is slightly higher than the reported value of $23.5 \mathrm{nM}$ [41]. 


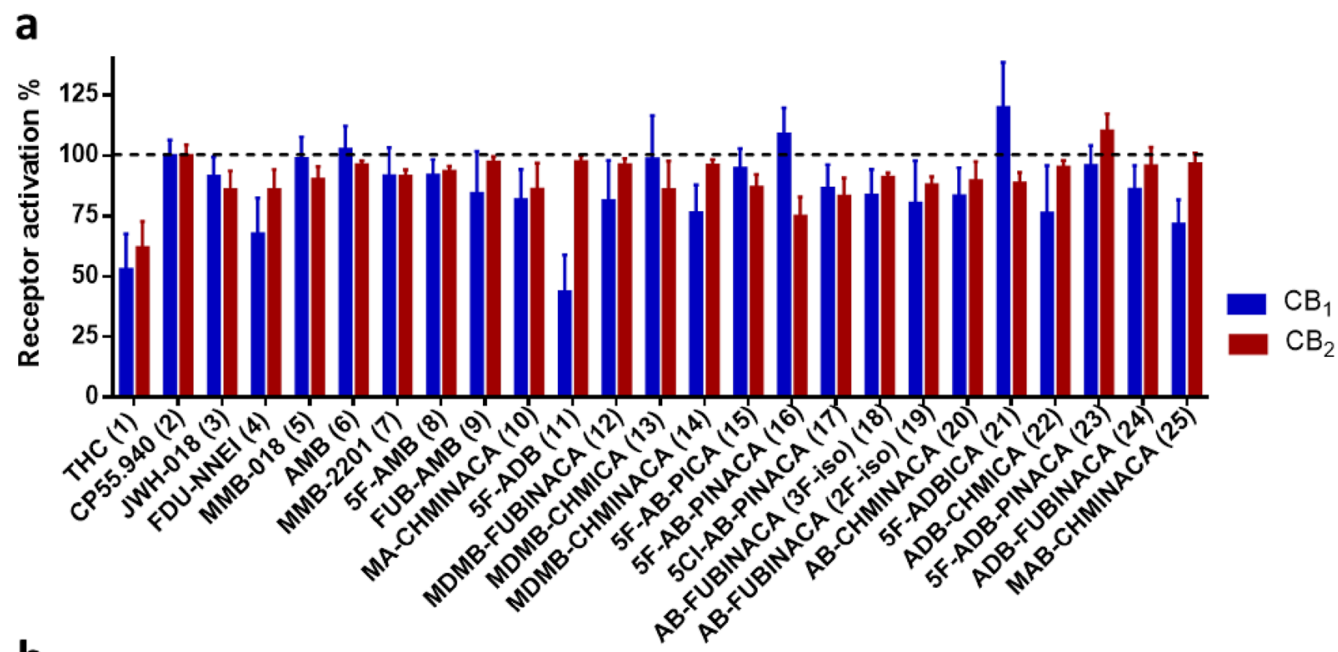

b

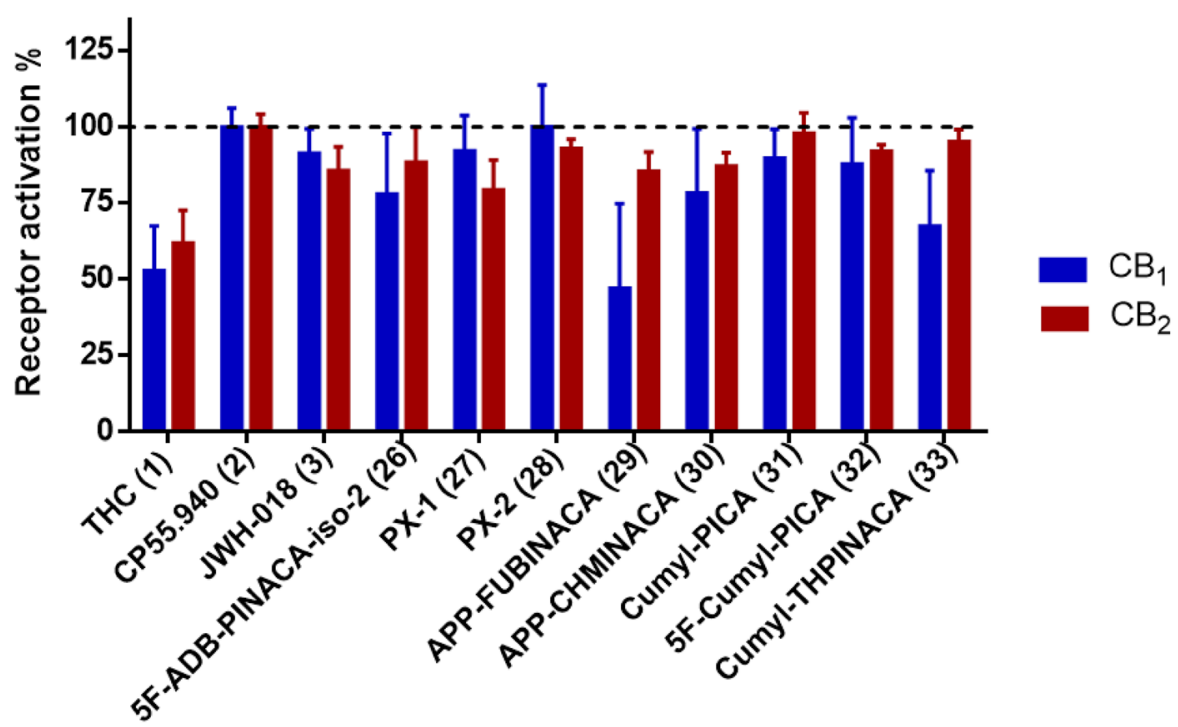

C

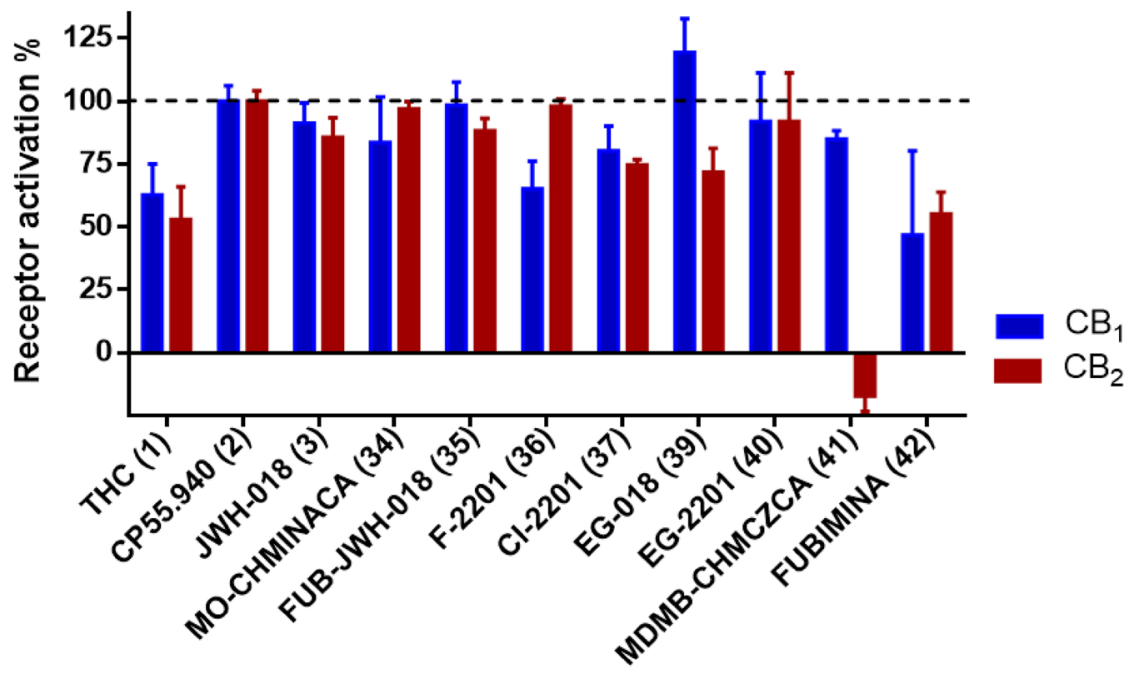


4Fig. 3 Receptor activation in cAMP accumulation assays. Receptor activation was normalized to the maximal effect observed with the full agonist CP55,940 $(1 \mu \mathrm{M})$. Compounds were applied at $10 \mu \mathrm{M}$ concentration in case their $K_{\mathrm{i}}$ value was $\geq 10 \mathrm{nM}$ and at $1 \mu \mathrm{M}$ concentration if their $K_{\mathrm{i}}$ value was $<10 \mathrm{nM}$. a Compounds $\mathbf{4 - 2 5}$; b compounds 26-33; c compounds 34-42

The presently investigated set of compounds complements our previous efforts to study the SARs of synthetic cannabinoids [25]. Of special interest is the observed scaffold hopping. Carbazole derivatives with a high affinity for $\mathrm{CB}$ receptors circumvent restriction by current law and display a new lead structure for $\mathrm{CB}$ receptor ligands. Further insight into the SARs is required to describe the potency profile of this compound class in more detail.

\section{CAMP accumulation assays}

As a next step, we investigated the compounds in cAMP accumulation assays, to obtain information on their functionality (Fig. 3). CB receptors are $G_{i}$ protein-coupled and thus reduce the levels of $\mathrm{CAMP}$ in the cells upon activation. We applied the compounds at either 10 or $1 \mu \mathrm{M}$ concentration depending on the $K_{\mathrm{i}}$ values measured in radioligand binding. If the $K_{\mathrm{i}}$ value was higher than $10 \mathrm{nM}$, we applied $10 \mu \mathrm{M}$ of the compound in our assays; otherwise the lower concentration of $1 \mu \mathrm{M}$ was assumed to be sufficient for maximal $\mathrm{CB}$ receptor activation. For comparison, we studied CP55,940 (1 $\mu \mathrm{M}), \Delta^{9}$-THC $(10 \mu \mathrm{M})$, and JWH-018 $(1 \mu \mathrm{M})$ under the same conditions at concentrations at which they exert their maximal effects. The cAMP response of the full agonist CP55,940 $(1 \mu \mathrm{M})$ was set at $100 \%$ receptor activation. a
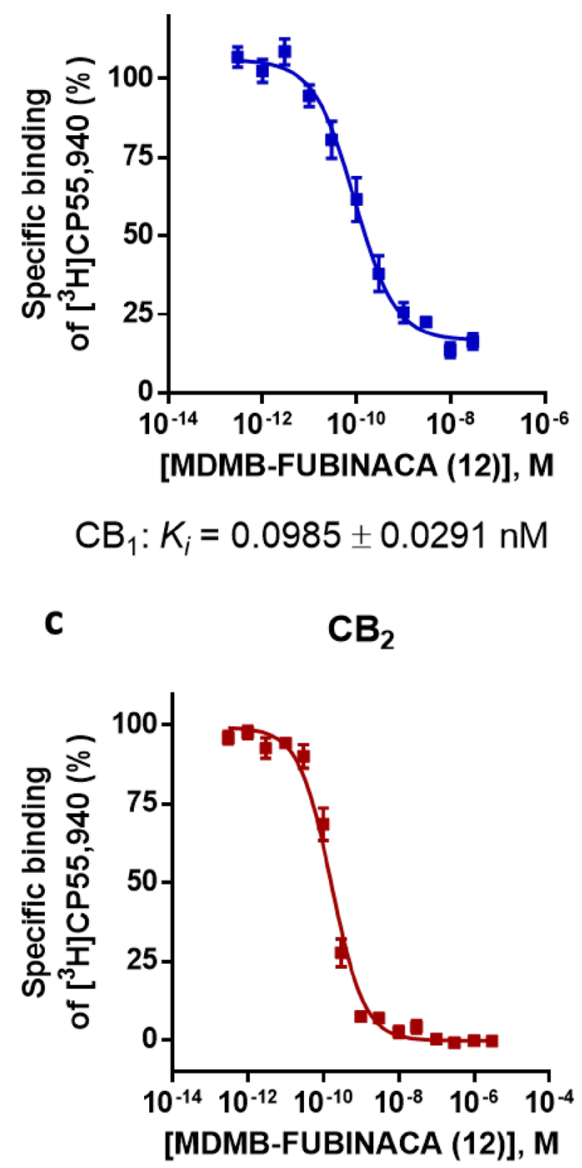

$\mathrm{CB}_{2}: K_{i}=0.130 \pm 0.010 \mathrm{nM}$ b $\quad \mathrm{CB}_{1}$

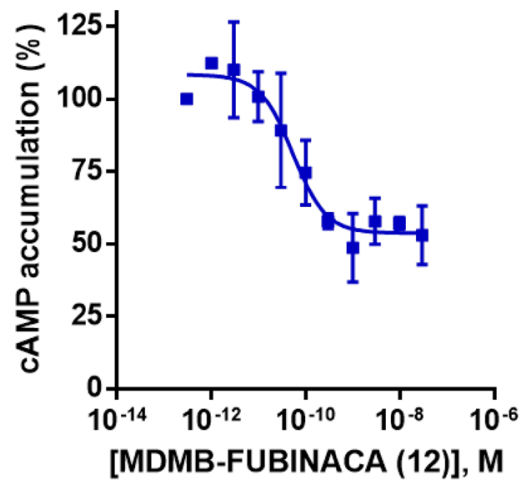

$\mathrm{CB}_{1}: \mathrm{EC}_{50}=0.0641 \pm 0.0364 \mathrm{nM}$

d

$\mathrm{CB}_{2}$

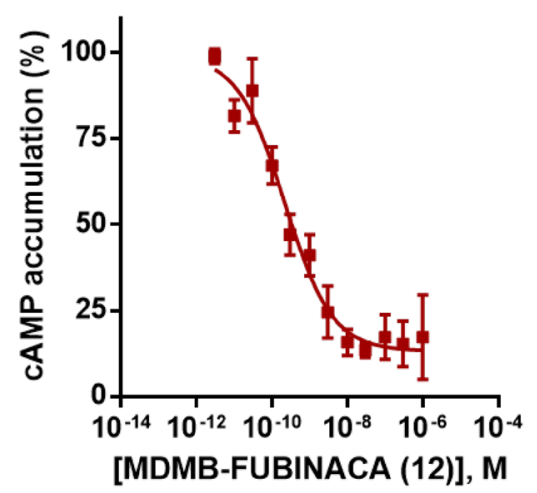

$\mathrm{CB}_{2}: \mathrm{EC}_{50}=0.756 \pm 0.578 \mathrm{nM}$
Fig. 4 Pharmacological characterization of MDMB-FUBINACA (12). a Affinity of MDMB-FUBINACA (12) for the cannabinoid receptor $\mathrm{CB}_{1}$ determined in radioligand binding studies. b Receptor activation of the cannabinoid $\mathrm{CB}_{1}$ receptor by MDMB-FUBINACA (12) determined in cAMP accumulation assays. c Affinity of MDMB-
FUBINACA (12) for the cannabinoid receptor $\mathrm{CB}_{2}$ determined in radioligand binding studies. $\mathbf{d}$ Receptor activation of the cannabinoid $\mathrm{CB}_{2}$ receptor by MDMB-FUBINACA (12) measured in cAMP accumulation assays 
a

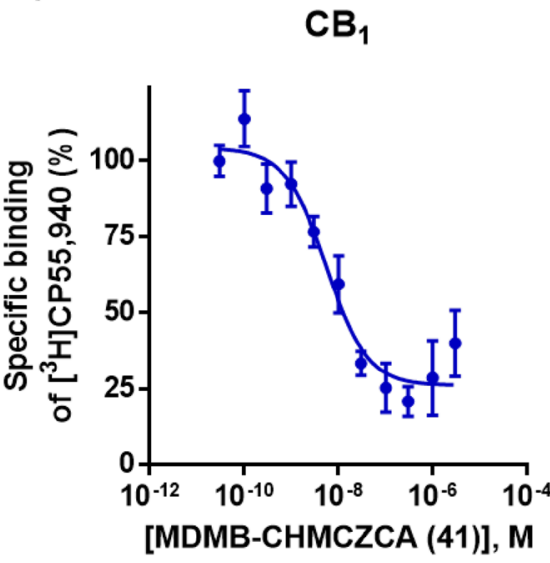

C

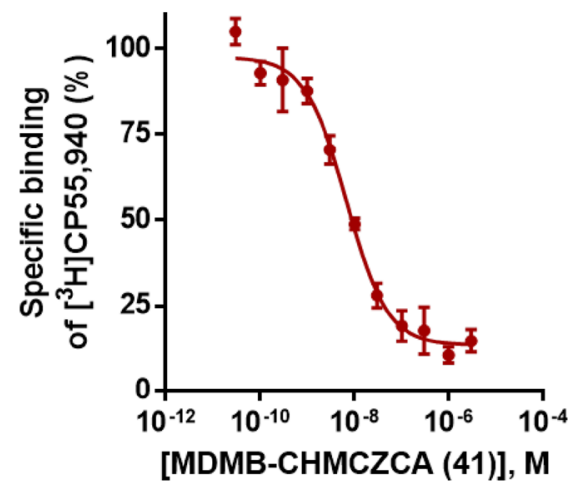

$\mathrm{CB}_{2}: K_{i}=6.67 \pm 1.40 \mathrm{nM}$ b

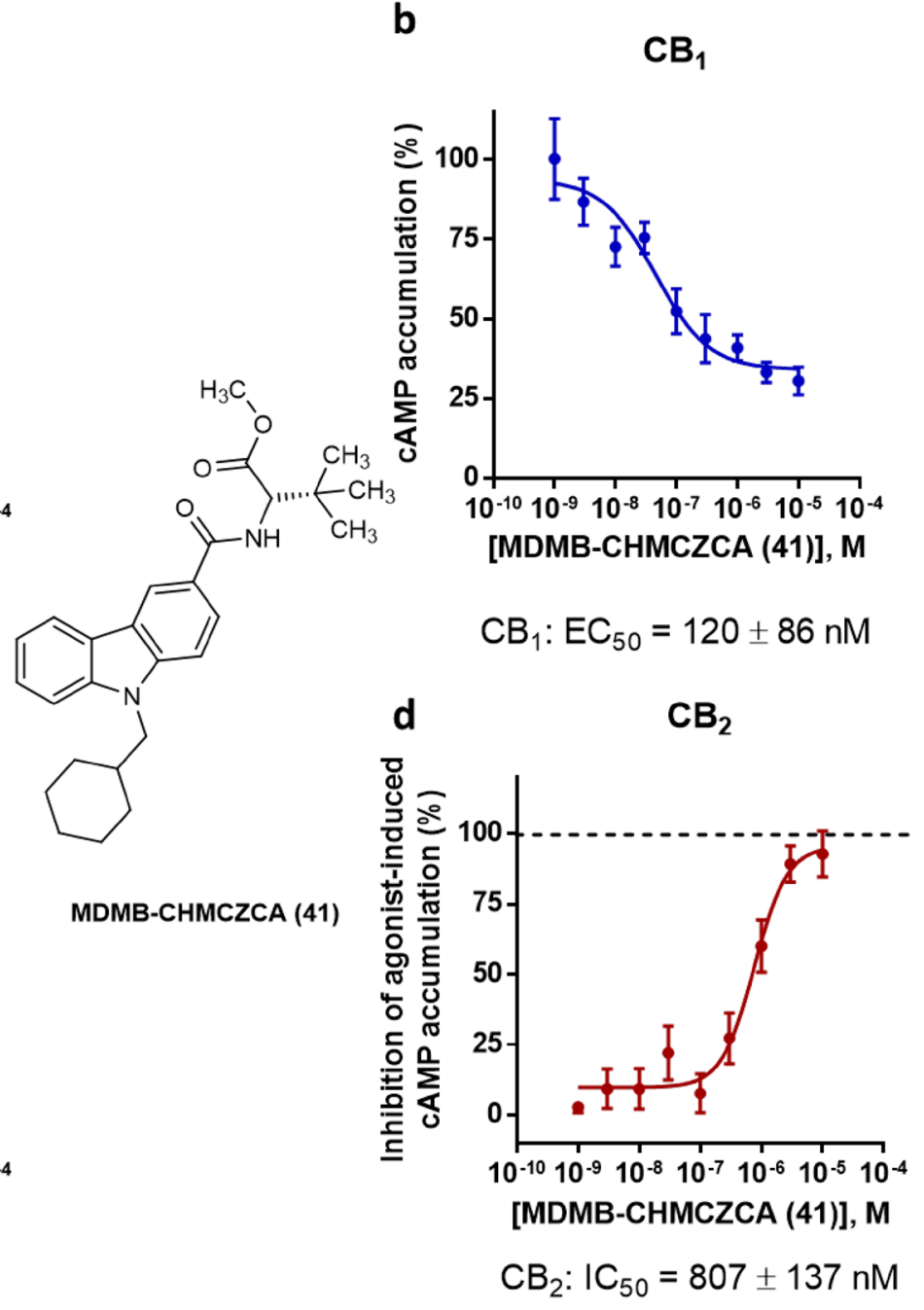

Fig. 5 Pharmacological characterization of the carbazole derivative MDMB-CHMCZCA (41). a Affinity of MDMB-CHMCZCA (41) for the cannabinoid receptor $\mathrm{CB}_{1}$ determined in radioligand binding studies. b Receptor activation of the cannabinoid $\mathrm{CB}_{1}$ receptor by MDMB-CHMCZCA (41) determined in cAMP accumulation assays.

Moreover, we determined the $\mathrm{EC}_{50}$ values of MDMBFUBINACA (12) by measuring full concentration inhibition curves. This compound had shown very low $K_{\mathrm{i}}$ values in radioligand binding assays indicating extremely high affinities, and in fact, the $\mathrm{EC}_{50}$ values determined in cAMP assays $\left[\mathrm{EC}_{50}\right.$ values of $0.0641 \mathrm{nM}\left(\mathrm{CB}_{1}\right)$ and $\left.0.756 \mathrm{nM}\left(\mathrm{CB}_{2}\right)\right]$ were in the same range as the $K_{\mathrm{i}}$ values measured in binding studies (see Fig. 4).

As can be seen in Fig. 3, almost all of the investigated compounds displayed agonistic behavior and showed high efficacy. Two compounds [5F-ADB (11) and APP-FUBIN$A C A$ (29)] displayed a partial activation of the $\mathrm{CB}_{1}$ receptor at a concentration of $10 \mu \mathrm{M}$. At the $\mathrm{CB}_{2}$ receptor however, they were found to act as full agonists (Fig. 3). FUBIMINA (42) showed only partial activation of both $\mathrm{CB}_{1}$ and $\mathrm{CB}_{2}$ c Affinity of MDMB-CHMCZCA (41) for the cannabinoid receptor $\mathrm{CB}_{2}$ determined in radioligand binding studies. $\mathbf{d}$ Inhibition of cannabinoid $\mathrm{CB}_{2}$ receptor activation induced by CP55,940 $(0.03 \mu \mathrm{M})$ by MDMB-CHMCZCA (41) measured in cAMP accumulation assays

receptors at a concentration of $10 \mu \mathrm{M}$; the activation was similar to that of $\Delta^{9}$-THC, which is a partial agonist. Full receptor activation by FUBIMINA (42) might not have been observed, due to its low affinity for the receptors. In accordance with this, Wiley et al. [41] observed a micromolar $\mathrm{EC}_{50}$ of $2470 \mathrm{nM}$ in $\left[{ }^{35} \mathrm{~S}\right] \mathrm{GTP} \gamma \mathrm{S}$ assays for FUBIMINA.

One compound completely lacked $\mathrm{CB}_{2}$ receptor activation: MDMB-CHMCZCA (41). However, MDMB-CHMCZCA (41) had shown high affinity for the $\mathrm{CB}_{2}$ receptor with a $K_{\mathrm{i}}$ value of $6.67 \mathrm{nM}$ in radioligand binding studies. A higher concentration of MDMB-CHMCZCA (41) at $10 \mu \mathrm{M}$ also failed to evoke an agonistic response (Fig. S3) on the $\mathrm{CB}_{2}$ receptor. Therefore, we investigated whether MDMB-CHMCZCA (41) might behave as a $\mathrm{CB}_{2}$ receptor antagonist. In Fig. 5d, the concentration-dependent 
a

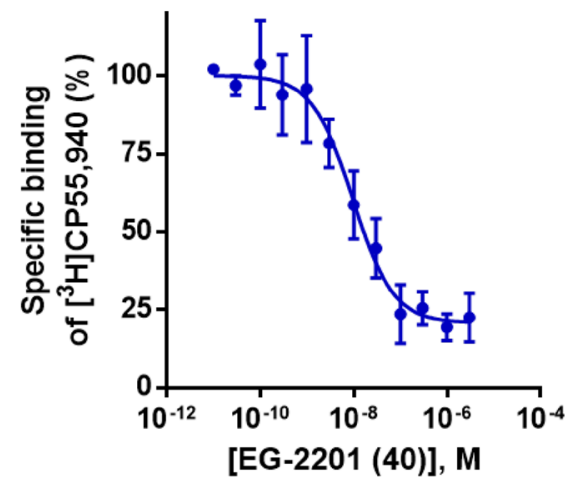

$\mathrm{CB}_{1}: K_{i}=22.4 \pm 12.8 \mathrm{nM}$

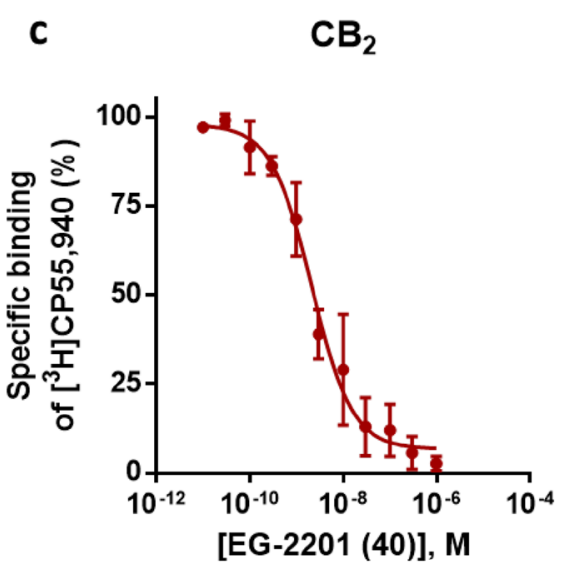

$\mathrm{CB}_{2}: K_{i}=4.36 \pm 2.91 \mathrm{nM}$ b<smiles>O=C(c1ccc2c(c1)c1ccccc1n2CCCCCF)c1cccc2ccccc12</smiles>

EG-2201 (40)

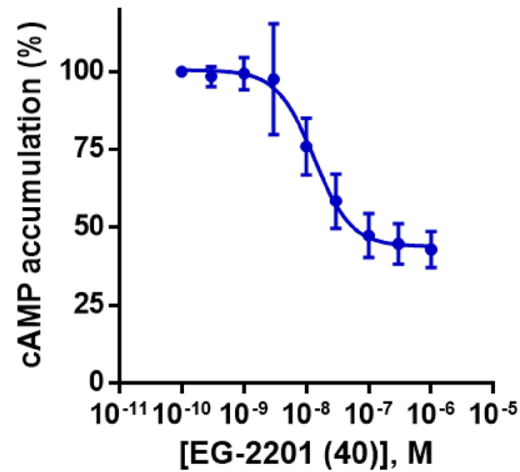

$\mathrm{CB}_{1}: \mathrm{EC}_{50}=15.6 \pm 6.3 \mathrm{nM}$

d $\quad \mathrm{CB}_{2}$

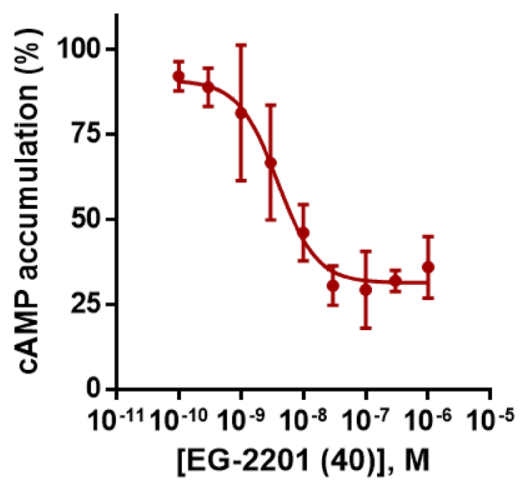

$\mathrm{CB}_{2}: \mathrm{EC}_{50}=5.65 \pm 2.31 \mathrm{nM}$
Fig. 6 Pharmacological characterization of EG-2201 (40). a Affinity of EG-2201 (40) for the cannabinoid receptor $\mathrm{CB}_{1}$ in radioligand binding studies. b Receptor activation of the cannabinoid $\mathrm{CB}_{1}$ receptor by EG-2201 (40) determined in cAMP accumulation assays, as compared to the effect of forskolin $(10 \mu \mathrm{M})$. c Affinity of EG-2201

response of MDMB-CHMCZCA (41) versus CP55,940 as an agonist $\left(0.03 \mu \mathrm{M}\right.$ corresponding to its $\mathrm{EC}_{80}$ value $)$ is shown. MDMB-CHMCZCA (41) displayed an $\mathrm{IC}_{50}$ value of $807 \pm 137 \mathrm{nM}$ under these conditions and clearly behaved as an antagonist at the $\mathrm{CB}_{2}$ receptor. The determined $\mathrm{IC}_{50}$ value in the cAMP assay was higher than the $K_{\mathrm{i}}$ value measured in radioligand binding studies. This might be due to the rather high concentration of CP55,940, that was applied, thus underestimating the inhibitory potency of 41. However, at the $\mathrm{CB}_{1}$ receptor MDMB-CHMCZCA (41) displayed agonistic behavior (Fig. 5b) with an $\mathrm{EC}_{50}$ value of $120 \mathrm{nM}$ and showed full efficacy as compared to the full agonist CP55,940 (Fig. S4). Another carbazole derivative, EG-2201 (40) was investigated and found to induce agonistic behavior at both $\mathrm{CB}$ receptor subtypes. Its respective $K_{\mathrm{i}}$ and $\mathrm{EC}_{50}$ values were similar $\left(\mathrm{CB}_{1} K_{\mathrm{i}}=22.4 \mathrm{nM}\right.$;
(40) for the cannabinoid receptor $\mathrm{CB}_{2}$ determined in radioligand binding studies. $\mathbf{d}$ Receptor activation of the cannabinoid $\mathrm{CB}_{2}$ receptor by EG-2201 (40) measured in cAMP accumulation assays, as compared to the effect of forskolin $(10 \mu \mathrm{M})$

$\mathrm{EC}_{50}=15.6 \mathrm{nM} ; \mathrm{CB}_{2} K_{\mathrm{i}}=4.36 \mathrm{nM}$ and $\mathrm{EC}_{50}=5.65 \mathrm{nM}$ (see Fig. 6). It showed an efficacy of $94 \%$ at $\mathrm{CB}_{1}$ and $77 \%$ at the $\mathrm{CB}_{2}$ receptor as compared to the maximum response of the full agonist CP55,940 (see Fig. S4).

There are not many $\mathrm{CB}_{2}$ receptor antagonists known in the literature. As tool compounds, the inverse agonists AM-630 (43), an indole derivative, and SR-144,528 (44), a bornyl-substituted pyrazole, structurally related to the $\mathrm{CB}_{1}$ receptor inverse agonist rimonabant, are frequently employed. They are both selective for $\mathrm{CB}_{2}$ versus $\mathrm{CB}_{1}[46$, 47]. This selectivity for the $\mathrm{CB}_{2}$ receptor might primarily be caused by the bulky lipophilic substituent attached to the heterocyclic core ( $\mathrm{R}^{1}$ position). Compared to these structures (see Fig. 7), MDMB-CHMCZCA (41) represents a new class of $\mathrm{CB}_{2}$ receptor antagonists. It shares the bulky substitution of the known $\mathrm{CB}_{2}$ inverse agonists at $\mathrm{R}^{1}$, 


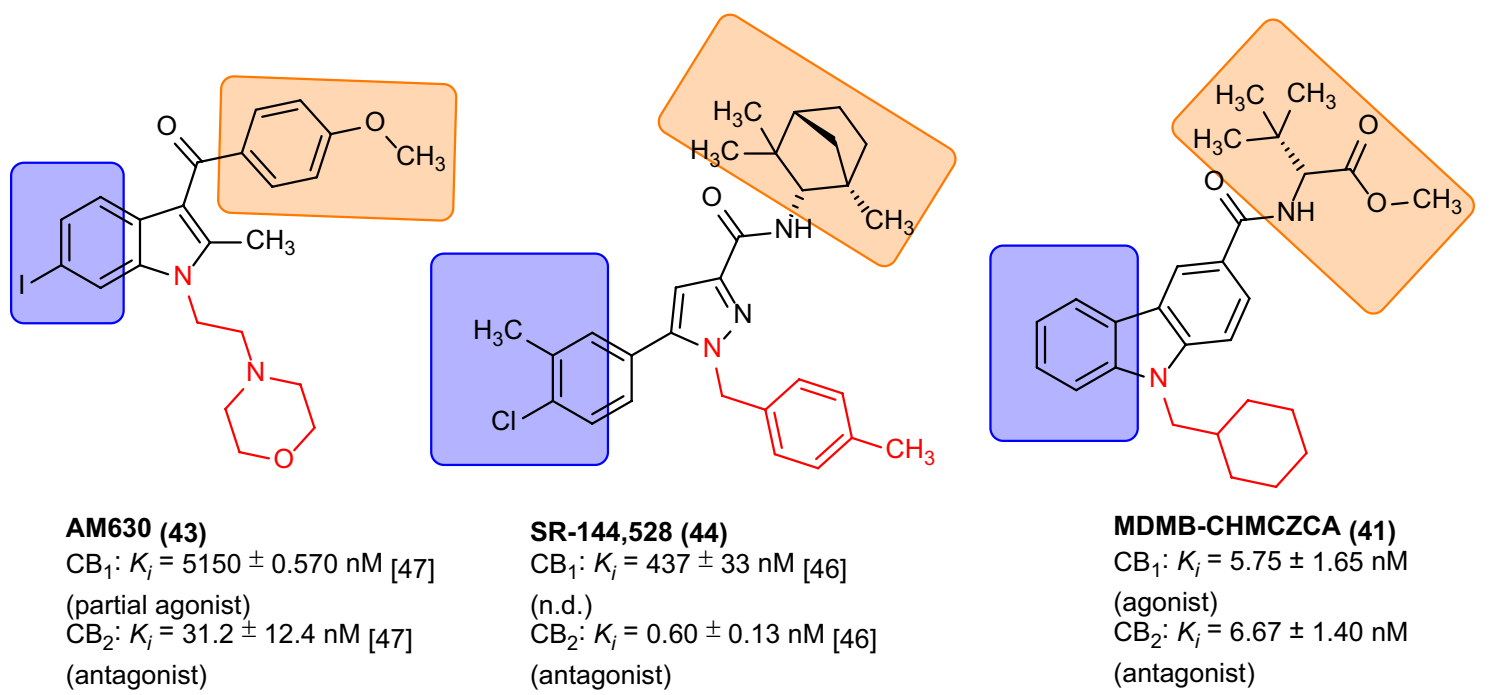

Fig. 7 Structural comparison of $\mathrm{CB}_{2}$ antagonists/inverse agonists [46, 47]

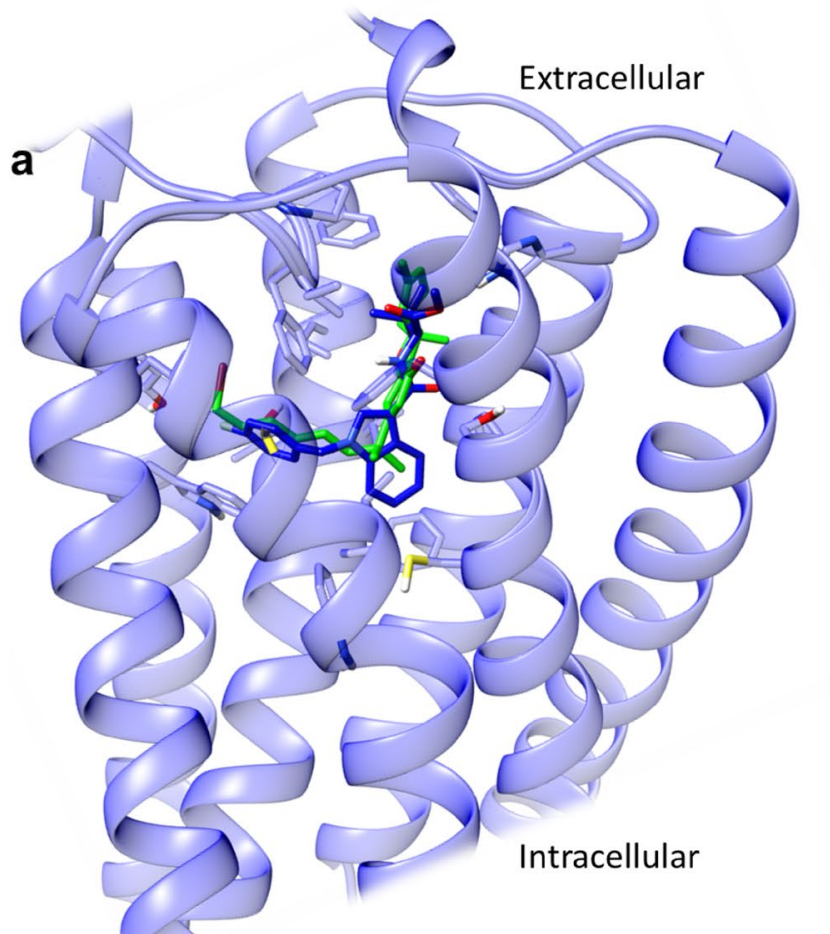

b

Based on 5XRA, $\mathrm{CB}_{1}$ agonist-bound state

Fig. 8 Docking of MDMB-FUBINACA (12) into the $\mathrm{CB}_{1}$ agonist state crystal structure reveals a plausible binding mode, in which the $p$-fluorobenzyl residue aligns with the alkyl side chain of the $\Delta^{9}$-THC-derived co-crystallized AM11542 (45, see Fig. 9)

which covers a similar space as the bornyl substitutent of 44 (Fig. 7). Moreover, AM-630 (43) and SR-144,528 (44), share bulky lipophilic substituents at position 6 of the indole, or the methyl-chloro-phenyl moiety, respectively. MDMBCHMCZCA (41) resembles these antagonists due to its

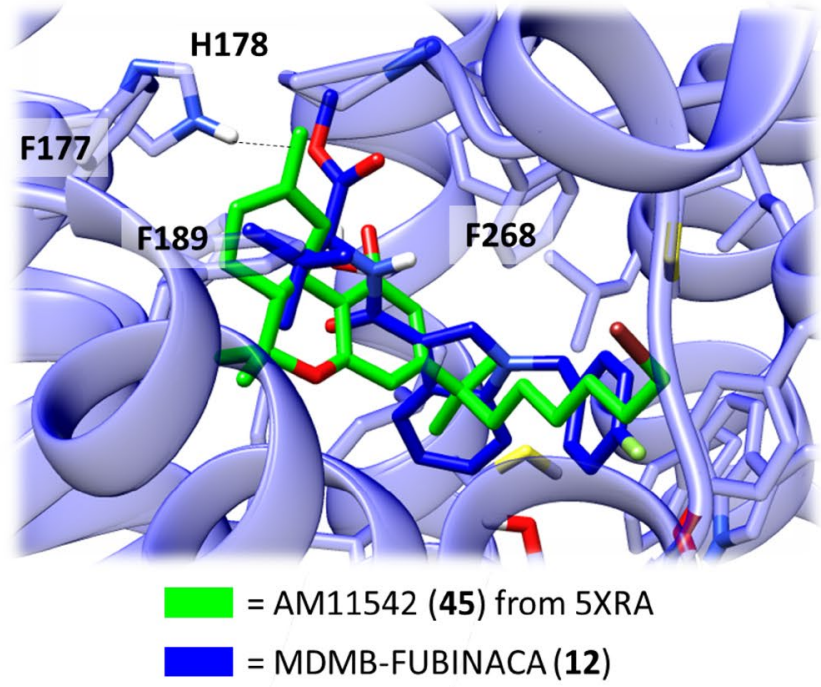

voluminous tricyclic carbazole structure. While agonists induce a conformational change of the receptors leading to activation, competitive antagonists are often larger than agonists and just block the orthosteric binding site thereby preventing binding of the agonist. 
Fig. 9 Overlay of the $\mathrm{CB}_{1}$ receptor agonists MDMBFUBINACA (12) and AM11542 (45)<smiles>COC(=O)[C@H](NC(=O)c1cn(Cc2ccc(F)cc2)c2ccccc12)C(C)(C)C</smiles>

MDMB-FUBINACA (12)<smiles>CC1=CC[C@H]2C(C1)c1c(O)cc(C(C)(C)CCCCCCBr)cc1OC2(C)C</smiles>

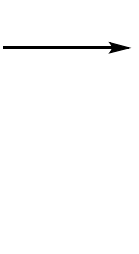

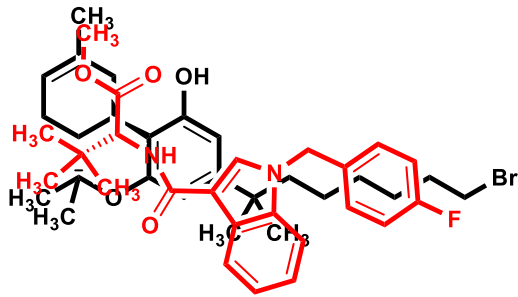

AM11542 (45)

\section{Molecular docking studies}

Recently, the crystal structure of the $\mathrm{CB}_{1}$ receptor was determined in both agonist- and antagonist-bound states with resolutions between 2.6 and $2.95 \AA[33,48,49]$. In a molecular docking study, we investigated possible binding poses and interactions of MDMB-FUBINACA (12), the most potent $\mathrm{CB}_{1}$ agonist of the present series $\left(\mathrm{CB}_{1} K_{\mathrm{i}}=0.0985 \mathrm{nM}\right)$. For modeling of its interaction with MDMB-FUBINACA (12), we used the agonist-bound template structures. In both published templates, $\Delta^{9}$-THC-derived compounds were co-crystallized with the receptor. Here we compare these poses with the hypothetical poses obtained by the docking of MDMBFUBINACA (12). The docking procedure was carried out using the Rosetta protein modeling suite of programs. The binding pose depicted by the largest cluster of low scoring models aligns the $p$-fluorobenzyl residue of MDMBFUBINACA (12) with the alkyl side chain of the $\Delta^{9}$-THC derivative AM11542 (45) bound in the crystal structure (see Figs. 8, 9). This pose is regarded as plausible because the length of the $p$-fluorobenzyl residue of MDMB-FUBINACA (12) is of importance for $\mathrm{CB}_{1}$-selectivity versus $\mathrm{CB}_{2}$ and closely resembles the lipophilic side chain of $\mathbf{4 5}$. The cocrystallized agonist 45 showed a $K_{\mathrm{i}}$ value of $0.11 \mathrm{nM}$ for the $\mathrm{CB}_{1}$ receptor [33], which is very similar to the affinity of MDMB-FUBINACA $\left(\mathbf{1 2}, K_{i} 0.0985 \mathrm{nM}\right)$. As shown in Figs. 8 and 9, the shape and size of both agonists as well as their lipophilicity and potential types of interaction aligned quite well. However, the template shows an interaction of serine-383 as a hydrogen bond donor to the phenolic group of the $\Delta^{9}$-THC-like compound. This was not observed in our model. Instead the oxygen atom of the ester function may participate in a hydrogen bond with histidine-178, an interaction that was not found for the co-crystallized compounds but could explain the equally high affinity of
MDMB-FUBINACA (12) to the $\mathrm{CB}_{1}$ receptor observed in the present study. A plausible structural overlay of $\Delta^{9}$-THC derivative AM11542 (45) and MDMB-FUBINACA (12) is depicted in Fig. 9. Alternative binding poses were less often sampled and showed a superimposition of the tert-leucine methyl ester residue with the alkyl side chain (compare Fig. S1).

\section{Potency at the orphan cannabinoid-interacting GPCRs GPR18 and GPR55}

The orphan receptors GPR18 and GPR55 can interact with certain natural and synthetic cannabinoids [26-29]. Recently, we found that some "Spice" constituents behaved as weak GPR55 antagonists [25]. Therefore, we investigated the new series of indole, indazole, benzimidazole and carbazole-derived structures in $\beta$-arrestin assays at GPR18 and GPR55 (Table 2). Most of the compounds were inactive. At GPR55, Cl-2201 (37) showed the highest antagonistic potency, tested versus the GPR55 agonist lysophosphatidylinositol (LPI, $1 \mu \mathrm{M}$ ), displaying an $\mathrm{IC}_{50}$ value of $7.12 \mu \mathrm{M}$. The fluorinated analogue F-2201 (36) was somewhat less potent with an $\mathrm{IC}_{50}$ value of $22.1 \mu \mathrm{M}$. Both of these compounds are derivatives of EAM-2201, which in our previous study had shown an $\mathrm{IC}_{50}$ value of $1.86 \mu \mathrm{M}$ [25]. For the lipophilic substitutions, the following rank order of potency was observed: ethyl $>$ methyl $>$ chloro $>$ fluoro. Therefore, it can be concluded that a lipophilic substitution in position 4 of the naphthyl residue was a requirement for GPR55 inhibition. The first amino acid-substituted derivatives to act as GPR55 antagonists are MO-CHMINACA (34) with an $\mathrm{IC}_{50}$ value of 9.29 $\mu \mathrm{M}$ and MDMB-CHMINACA (14) with an $\mathrm{IC}_{50}$ value of $10.3 \mu \mathrm{M}$. At GPR18 weak inhibitory potency was observed for MDMB-CHMICA (13), MO-CHMINACA (34) and MDMB-CHMCZCA (41). 
Table 2 Activity of test compounds in $\beta$-arrestin assays at human GPR55 and GPR18

\begin{tabular}{|c|c|c|c|c|c|}
\hline & \multirow[t]{2}{*}{ Compd } & \multicolumn{2}{|l|}{ Human GPR55 } & \multicolumn{2}{|l|}{ Human GPR18 } \\
\hline & & $\mathrm{EC}_{50}(\mu \mathrm{M})(\%$ activation $)$ & $\mathrm{IC}_{50}(\mu \mathrm{M})(\%$ inhibition) & $\mathrm{EC}_{50}(\mu \mathrm{M})(\%$ activation $)$ & $\mathrm{IC}_{50}(\mu \mathrm{M})(\%$ inhibition $)$ \\
\hline 1 & $\Delta^{9}-\mathrm{THC}$ & - & $14.2[52]$ & $4.61[52]$ & - \\
\hline 2 & CP55,940 & - & $1.61[53]$ & - & $5.99[52]$ \\
\hline \multicolumn{6}{|c|}{ 3-Amido-indole and -indazoles (A) } \\
\hline 4 & FDU-NNEI & $>10(13 \%)$ & $>10(2 \%)$ & $>10(20 \%)$ & $>10(-1 \%)$ \\
\hline 5 & MMB-018 & $>10(5 \%)$ & $>10(5 \%)$ & $>10(13 \%)$ & $>10(-4 \%)$ \\
\hline 6 & AMB & $>10(15 \%)$ & $>10(28 \%)$ & $>10(42 \%)(\mathrm{n}=1)$ & $>10(15 \%)$ \\
\hline 7 & MMB-2201 & $>10(5 \%)$ & $>10(-10 \%)$ & $>10(2 \%)$ & $>10(-6 \%)$ \\
\hline 8 & 5F-AMB & $>10(14 \%)$ & $>10(-6 \%)$ & $>10(1 \%)$ & $>10(-5 \%)$ \\
\hline 9 & FUB-AMB & $>10(4 \%)$ & $>10(17 \%)$ & $>10(-2 \%)$ & $>10(11 \%)$ \\
\hline 10 & MA-CHMINACA & $>10(2 \%)$ & $>10(31 \%)$ & $>10(19 \%)$ & $>10(10 \%)$ \\
\hline 11 & $5 \mathrm{~F}-\mathrm{ADB}$ & $>10(0 \%)$ & $>10(6 \%)$ & $>10(10 \%)$ & $>10(-10 \%)$ \\
\hline 12 & MDMB-FUBINACA & $>10(-4 \%)$ & $>10(30 \%)$ & $>10(18 \%)$ & $>10(31 \%)$ \\
\hline 13 & MDMB-CHMICA & $>10(5 \%)$ & $>10(38 \%)$ & $>10(5 \%)$ & $14.1 \pm 3.1^{\mathrm{a}}$ \\
\hline 14 & MDMB-CHMINACA & $>10(-5 \%)$ & $10.3 \pm 1.7$ & $>10(27 \%)$ & $\approx 10(51 \%)$ \\
\hline 15 & 5F-ABPICA & $>10(10 \%)$ & $>10(-6 \%)$ & $>10(23 \%)$ & $>10(-25 \%)$ \\
\hline 16 & 5F-AB-PINACA & $>10(15 \%)$ & $>10(-3 \%)$ & $>10(12 \%)$ & $>10(10 \%)$ \\
\hline 17 & 5Cl-AB-PINACA & $>10(17 \%)$ & $>10(-8 \%)$ & $>10(4 \%)$ & $>10(0 \%)$ \\
\hline 18 & $\begin{array}{l}\text { AB-FUBINACA (3F-benzyl- } \\
\text { isomer) }\end{array}$ & $>10(11 \%)$ & $>10(-7 \%)$ & $>10(10 \%)$ & $>10(-11 \%)$ \\
\hline 19 & $\begin{array}{l}\text { AB-FUBINACA (2F-benzyl- } \\
\text { isomer) }\end{array}$ & $>10(15 \%)$ & $>10(-9 \%)$ & $>10(11 \%)$ & $>10(-5 \%)$ \\
\hline 20 & AB-CHMINACA & $>10(8 \%)$ & $>10(-3 \%)$ & $>10(13 \%)$ & $>10(11 \%)$ \\
\hline 21 & 5F-ADBICA & $>10(8 \%)$ & $>10(-8 \%)$ & $>10(27 \%)$ & $>10(-11 \%)$ \\
\hline 22 & ADB-CHMICA & $>10(17 \%)$ & $>10(8 \%)$ & $>10(8 \%)$ & $>10(14 \%)$ \\
\hline 23 & 5F-ADB-PINACA & $>10(18 \%)$ & $>10(-2 \%)$ & $>10(9 \%)$ & $>10(21 \%)$ \\
\hline 24 & ADB-FUBINACA & $>10(7 \%)$ & $>10(-3 \%)$ & $>10(7 \%)$ & $>10(16 \%)$ \\
\hline 25 & MAB-CHMINACA & $>10(16 \%)$ & $>10(-7 \%)$ & $>10(6 \%)$ & $>10(10 \%)$ \\
\hline 26 & 5F-ADB-PINACA-isomer 2 & $>10(2 \%)$ & $>10(-6 \%)$ & $>10(8 \%)$ & $>10(-11 \%)$ \\
\hline 27 & PX-1 & $>10(6 \%)$ & $>10(1 \%)$ & $>10(15 \%)$ & $>10(-16 \%)$ \\
\hline 28 & PX-2 & $>10(16 \%)$ & $>10(-10 \%)$ & $>10(-4 \%)$ & $>10(15 \%)$ \\
\hline 29 & APP-FUBINACA & $>10(26 \%)$ & $>10(-9 \%)$ & $>10(4 \%)$ & $>10(21 \%)$ \\
\hline 30 & APP-CHMINACA & $>10(11 \%)$ & $>10(9 \%)$ & $>10(5 \%)$ & $\approx 10(57 \%)$ \\
\hline 31 & Cumyl-PICA & $>10(11 \%)$ & $>10(3 \%)$ & $>10(19 \%)$ & $>10(-7 \%)$ \\
\hline 32 & 5F-Cumyl-PICA & $>10(14 \%)$ & $>10(-6 \%)$ & $>10(16 \%)$ & $>10(-3 \%)$ \\
\hline 33 & Cumyl-THPINACA & $>10(11 \%)$ & $>10(7 \%)$ & $>10(11 \%)$ & $>10(9 \%)$ \\
\hline \multicolumn{6}{|c|}{ Ester-substituted indazoles (B) } \\
\hline 34 & MO-CHMINACA & $>10(1 \%)$ & $9.29 \pm 1.7$ & $>10(0 \%)$ & $12.6 \pm 3.5^{\mathrm{a}}$ \\
\hline \multicolumn{6}{|c|}{ 3-Carbonyl-indoles (C) } \\
\hline 35 & FUB-JWH-018 & $>10(7 \%)$ & $>10(30 \%)$ & $>10(20 \%)$ & $>10(30 \%)$ \\
\hline 36 & F-2201 & $>10(-10 \%)$ & $22.1 \pm 12.2^{\mathrm{a}}$ & $>10(18 \%)$ & $>10(14 \%)$ \\
\hline 37 & $\mathrm{Cl}-2201$ & $>10(-1 \%)$ & $7.12 \pm 1.26$ & $>10(16 \%)$ & $>10(4 \%)$ \\
\hline \multicolumn{6}{|c|}{ 3-Carbonyl-carbazoles (E) } \\
\hline 39 & EG-018 & $>10(0 \%)^{\mathrm{b}}$ & $>10(1 \%)^{\mathrm{b}}$ & $>10(2 \%)^{\mathrm{b}}$ & $>10(-11 \%)$ \\
\hline 40 & EG-2201 & $>10(-3 \%)$ & $>10(3 \%)$ & $>10(3 \%)$ & $>10(7 \%)$ \\
\hline 41 & MDMB-CHMCZCA & $>10(-8 \%)$ & $>10(25 \%)$ & $>10(-35 \%)$ & $9.66 \pm 1.20^{\mathrm{a}}$ \\
\hline \multicolumn{6}{|c|}{ Carbonyl-benzimidazole (F) } \\
\hline 42 & FUBIMINA & $>10(16 \%)$ & $>10(44 \%)$ & $>10(42 \%)^{\mathrm{c}}$ & $>10(14 \%)^{\mathrm{b}}$ \\
\hline
\end{tabular}

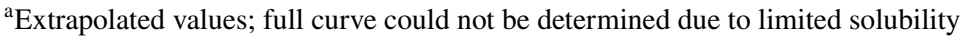

${ }^{\mathrm{b}} n=2$

${ }^{\mathrm{c}} n=1$ 
These results indicate that the investigated series of $\mathrm{CB}$ receptor ligands is highly selective versus GPR 18 and GPR55. None of the compounds was able to activate these orphan receptors. Some acted as antagonists at micromolar concentrations, but considerable efforts would be required to optimize these new lead structures to obtain potent GPR18or GPR55-selective antagonists.

\section{Conclusions}

In this study, we continued to investigate the SARs of illicitly used constituents of "Spice" preparations. We investigated the affinities of a large series of compounds in radioligand binding assays and found MDMB-FUBINACA (12) belonging to the class of 3-amidoindazoles to be an extremely potent fully efficacious agonist showing picomolar affinities for $\mathrm{CB}_{1}(98.5 \mathrm{pM})$ and $\mathrm{CB}_{2}(130 \mathrm{pM})$ receptors. For this compound class severe side effects had been reported, as for example the "zombie outbreak" that was related to AMB-FUBINACA [50], a structurally related compound. The extremely high potency of these compounds might be one of the reasons for their severe side effects. The SARs, especially regarding the $R^{2}$ residue, were consistent with the patterns observed in our previous study [25]. Lipophilic substituents had been introduced, e.g., a 5-fluoropentyl side chain, or a $p$-fluorobenzyl residue, which had similar properties as the pentyl side chain found in the JWH-compounds such as JWH-018. For MDMB-FUBINACA (12), we performed $\mathrm{CB}_{1}$ receptor docking studies and observed a pose comparable to $\Delta^{9}$-THC-derived compounds. In addition to the well-described group of alkylindoles and indazoles, we investigated a series of carbazoles, which showed singledigit nanomolar affinity at both $\mathrm{CB}$ receptor subtypes. One of these compounds, MDMB-CHMCZCA (41), unexpectedly turned out to be a full agonist at the $\mathrm{CB}_{1}$, but an antagonist at $\mathrm{CB}_{2}$ receptors, with $K_{i}$ values at $\mathrm{CB}_{1}$ of $5.75 \mathrm{nM}$ and at $\mathrm{CB}_{2}$ of $6.67 \mathrm{nM}$, and $\mathrm{EC}_{50}$ values of $120 \mathrm{nM}$ at $\mathrm{CB}_{1}$ and of $807 \mathrm{nM}$ at $\mathrm{CB}_{2}$ receptors in cAMP accumulation assays. According to our knowledge, this combination of full $\mathrm{CB}_{1}$-agonistic and $\mathrm{CB}_{2}$-antagonistic activities is unique. Although $\mathrm{CB}_{2}$ receptor antagonists and inverse agonists have been studied for some time, their clinical utility is still under investigation. The expression of $\mathrm{CB}_{2}$ receptors in the immune system suggests immunomodulatory effects for $\mathrm{CB}_{2}$ receptor ligands. The group of carbazoles showed nanomolar affinities for the $\mathrm{CB}_{1}$ receptor and behaved as full agonists in cAMP accumulation assays. They circumvent the structural features described in the NpSG by scaffold hopping. This new class of synthetic cannabinoids needs to be further studied to fully investigate its SARs and potential for abuse. The present study may contribute to guiding future decisions on the restriction of carbazole-derived and related synthetic cannabinoids.

Acknowledgments We thank Marion Schneider for performing LCMS analyses. CTS was supported by a BAYER Ph.D. fellowship; CEM and CTS are grateful for support by the Deutsche Forschungsgemeinschaft (Research Training Group GRK1873). We thank Prof. Volker Auwärter and Verena Angerer from the Institute of Forensic Medicine in Freiburg, Germany, for providing MDMB-CHMCZCA (41).

\section{Compliance of ethical standards}

Conflict of interest The authors declare that they have no conflict of interest.

Ethical approval This article does not contain any studies with human participants or animals performed by any of the authors.

Open Access This article is distributed under the terms of the Creative Commons Attribution 4.0 International License (http://creativeco mmons.org/licenses/by/4.0/), which permits unrestricted use, distribution, and reproduction in any medium, provided you give appropriate credit to the original author(s) and the source, provide a link to the Creative Commons license, and indicate if changes were made.

\section{References}

1. Lindigkeit R, Boehme A, Eiserloh I, Luebbecke M, Wiggermann M, Ernst L, Beuerle T (2009) Spice: a never ending story? Forensic Sci Int 191:58-63

2. European Monitoring Centre for Drugs and Drug Addiction (EMCDDA) (2017) European drug report 2017: trends and developments. https://doi.org/10.2810/610791

3. European Monitoring Centre for Drugs and Drug Addiction (EMCDDA) (2009) Thematic papers: understanding the 'Spice' phenomenon. https://doi.org/10.2810/27063

4. Davidson C, Opacka-Juffry J, Arevalo-Martin A, Garcia-Ovejero D, Molina-Holgado E, Molina-Holgado F (2017) Spicing up pharmacology. Adv Pharmacol 80:135-168

5. European Monitoring Centre for Drugs and Drug Addiction (EMCDDA) (2015) European drug report 2015: trends and developments. https://doi.org/10.2810/314903

6. Fredriksson R, Lagerstrom MC, Lundin L-G, Schioth HB (2003) The G-protein-coupled receptors in the human genome form five main families. Phylogenetic analysis, paralogon groups, and fingerprints. Mol Pharmacol 63:1256-1272

7. Ashton CH (2001) Pharmacology and effects of cannabis: a brief review. Br J Psychiatry 178:101-106

8. Cabral GA, Raborn ES, Griffin L, Dennis J, Marciano-Cabral F (2008) $\mathrm{CB}_{2}$ receptors in the brain: role in central immune function. Br J Pharmacol 153:240-251

9. Pacher P, Mechoulam R (2011) Is lipid signaling through cannabinoid 2 receptors part of a protective system? Prog Lipid Res 50:193-211

10. Herkenham M, Lynn AB, Johnson MR, Melvin LS, de Costa BR, Rice KC (1991) Characterization and localization of cannabinoid receptors in rat brain: a quantitative in vitro autoradiographic study. J Neurosci 11:563-583 
11. Munro S, Thomas KL, Abu-Shaar M (1993) Molecular characterization of a peripheral receptor for cannabinoids. Nature 365:61-65

12. Pertwee RG, Howlett AC, Abood ME, Alexander SPH, Di Marzo V, Elphick MR, Greasley PJ, Hansen HS, Kunos G, Mackie K, Mechoulam R, Ross RA (2010) International Union of Basic and Clinical Pharmacology. LXXIX. Cannabinoid receptors and their ligands: beyond $\mathrm{CB}_{1}$ and $\mathrm{CB}_{2}$. Pharmacol Rev 62:588-631

13. Miller AM, Stella $N$ (2008) $\mathrm{CB}_{2}$ receptor-mediated migration of immune cells: it can go either way. Br J Pharmacol 153:299-308

14. Pertwee RG (2008) The diverse $\mathrm{CB}_{1}$ and $\mathrm{CB}_{2}$ receptor pharmacology of three plant cannabinoids: $\Delta^{9}$-tetrahydrocannabinol, cannabidiol and $\Delta^{9}$-tetrahydrocannabivarin. $\mathrm{Br} \mathrm{J}$ Pharmacol 153:199-215

15. Pertwee RG (2006) The pharmacology of cannabinoid receptors and their ligands: an overview. Int J Obes 30 Suppl 1:13-18

16. Riederer AM, Campleman SL, Carlson RG, Boyer EW, Manini AF, Wax PM, Brent JA (2016) Acute poisonings from synthetic cannabinoids-50 U.S. Toxicology Investigators Consortium Registry Sites, 2010-2015. MMWR Morb Mortal Wkly Rep 65:692-695

17. U.S. Department of Justice, Drug Enforcement Administration (2018) Control division part 1308-schedules of controlled substances. 11 Schedule 1. https://www.deadversion.usdoj .gov/21cfr/cfr/1308/1308_11.htm. Accessed 6 March 2018

18. Bundesministerium der Justiz und für Verbraucherschutz (2016) Gesetz zur Bekämpfung der Verbreitung neuer psychoaktiver Stoffe. BGB1 I Nr. 55

19. Bundesministerium für Verfassung, Reformen, Deregulierung und Justiz (2011) Bundesgesetz über den Schutz vor Gesundheitsgefahren im Zusammenhang mit Neuen Psychoaktiven Substanzen. BGB1. I Nr. 146/2011

20. Die Bundesversammlung der Schweizerischen Eidgenossenschaft (2011) Bundesgesetz über die Betäubungsmittel und die psychotropen Stoffe. SR 812.121

21. Huffman JW, Dai D, Martin BR, Compton DR (1994) Design, synthesis and pharmacology of cannabimimetic indoles. Bioorg Med Chem Lett 4:563-566

22. Huffman JW, Zengin G, Wu M-J, Lu J, Hynd G, Bushell K, Thompson ALS, Bushell S, Tartal C, Hurst DP, Reggio PH, Selley DE, Cassidy MP, Wiley JL, Martin BR (2005) Structureactivity relationships for 1-alkyl-3-(1-naphthoyl)indoles at the cannabinoid $\mathrm{CB}_{1}$ and $\mathrm{CB}_{2}$ receptors: steric and electronic effects of naphthoyl substituents. New highly selective $\mathrm{CB}_{2}$ receptor agonists. Bioorg Med Chem 13:89-112

23. Uchiyama N, Kikura-Hanajiri R, Kawahara N, Goda Y (2009) Identification of a cannabimimetic indole as a designer drug in a herbal product. Forensic Toxicol 27:61-66

24. Auwärter V, Dresen S, Weinmann W, Müller M, Pütz M, Ferreirós N (2009) 'Spice' and other herbal blends: harmless incense or cannabinoid designer drugs? J Mass Spectrom 44:832-837

25. Hess C, Schoeder CT, Pillaiyar T, Madea B, Müller CE (2016) Pharmacological evaluation of synthetic cannabinoids identified as constituents of spice. Forensic Toxicol 34:329-343

26. Ryberg E, Larsson N, Sjogren S, Hjorth S, Hermansson N-O, Leonova J, Elebring T, Nilsson K, Drmota T, Greasley PJ (2007) The orphan receptor GPR55 is a novel cannabinoid receptor. Br J Pharmacol 152:1092-1101

27. McHugh D, Page J, Dunn E, Bradshaw HB (2012) $\Delta^{9}$ Tetrahydrocannabinol and $\mathrm{N}$-arachidonyl glycine are full agonists at GPR18 receptors and induce migration in human endometrial HEC-1B cells. Br J Pharmacol 165:2414-2424

28. Kapur A, Zhao P, Sharir H, Bai Y, Caron MG, Barak LS, Abood ME (2009) Atypical responsiveness of the orphan receptor GPR55 to cannabinoid ligands. J Biol Chem 284:29817-29827
29. Rempel V, Atzler K, Behrenswerth A, Karcz T, Schoeder C, Hinz S, Kaleta M, Thimm D, Kiec-Kononowicz K, Müller CE (2014) Bicyclic imidazole-4-one derivatives as: a new class of antagonists for the orphan G protein-coupled receptors GPR18 and GPR55. Med Chem Commun 5:632-649

30. Nordstedt C, Fredholm BB (1990) A modification of a proteinbinding method for rapid quantification of cAMP in cell-culture supernatants and body fluid. Anal Biochem 189:231-234

31. Bender BJ, Cisneros A 3rd, Duran AM, Finn JA, Fu D, Lokits AD, Mueller BK, Sangha AK, Sauer MF, Sevy AM, Sliwoski G, Sheehan JH, DiMaio F, Meiler J, Moretti R (2016) Protocols for molecular modeling with Rosetta3 and RosettaScripts. Biochemistry 55:4748-4763

32. Kaufmann KW, Lemmon GH, Deluca SL, Sheehan JH, Meiler J (2010) Practically useful: what the Rosetta protein modeling suite can do for you. Biochemistry 49:2987-2998

33. Hua T, Vemuri K, Nikas SP, Laprairie RB, Wu Y, Qu L, Pu M, Korde A, Jiang S, Ho J-H, Han GW, Ding K, Li X, Liu H, Hanson MA, Zhao S, Bohn LM, Makriyannis A, Stevens RC, Liu Z-J (2017) Crystal structures of agonist-bound human cannabinoid receptor $\mathrm{CB}_{1}$. Nature 547:468-471

34. Kothiwale S, Mendenhall JL, Meiler J (2015) BCL:conf: small molecule conformational sampling using a knowledge based rotamer library. J Chemin 7:47. https://doi.org/10.1186/A1332 1-015-0095-1

35. Pettersen EF, Goddard TD, Huang CC, Couch GS, Greenblatt DM, Meng EC, Ferrin TE (2004) UCSF Chimera-a visualization system for exploratory research and analysis. J Comput Chem 25:1605-1612

36. Fujioka M, Omori N (2012) Subtleties in GPCR drug discovery: a medicinal chemistry perspective. Drug Discov Today 17:1133-1138

37. Buchler IP, Hayes MJ, Hedge SG, Hockerman SL, Jones DE, Kortum SW, Rico JG, Tenbrick RE, Wu KK (2009) Indazole derivatives. WO 2009/106982/A1

38. Banister SD, Longworth M, Kevin R, Sachdev S, Santiago M, Stuart J, Mack JBC, Glass M, McGregor IS, Connor M, Kassiou M (2016) Pharmacology of valinate and tert-leucinate synthetic cannabinoids 5F-AMBICA, 5F-AMB, 5F-ADB, AMB-FUBINACA, MDMB-FUBINACA, MDMB-CHMICA, and their analogues. ACS Chem Neurosci 7:1241-1254

39. Adamowicz P (2016) Fatal intoxication with synthetic cannabinoid MDMB-CHMICA. Forensic Sci Int 261:e5-e10

40. Bäckberg M, Tworek L, Beck O, Helander A (2017) Analytically confirmed intoxications involving MDMB-CHMICA from the STRIDA project. J Med Toxicol 13:52-60

41. Wiley JL, Marusich JA, Lefever TW, Antonazzo KR, Wallgren MT, Cortes RA, Patel PR, Grabenauer M, Moore KN, Thomas BF (2015) AB-CHMINACA, AB-PINACA, and FUBIMINA: affinity and potency of novel synthetic cannabinoids in producing $\Delta^{9}$ tetrahydrocannabinol-like effects in mice. J Pharmacol Exp Ther 354:328-339

42. Banister SD, Moir M, Stuart J, Kevin RC, Wood KE, Longworth M, Wilkinson SM, Beinat C, Buchanan AS, Glass M, Connor M, McGregor IS, Kassiou M (2015) Pharmacology of indole and indazole synthetic cannabinoid designer drugs AB-FUBINACA, ADB-FUBINACA, AB-PINACA, ADB-PINACA, 5F-AB-PINACA, 5F-ADB-PINACA, ADBICA, and 5F-ADBICA. ACS Chem Neurosci 6:1546-1559

43. Bowden MJ, Williamson JPB (2014) Cannabinoid compounds. WO2014/167530/A1

44. Uchiyama N, Shimokawa Y, Matsuda S, Kawamura M, Kikura-Hanajiri R, Goda Y (2014) Two new synthetic cannabinoids, AM-2201 benzimidazole analog (FUBIMINA) and (4-methylpiperazin-1-yl)(1-pentyl- $1 H$-indol-3-yl)methanone (MEPIRAPIM), and three phenethylamine derivatives, 
25H-NBOMe 3,4,5-trimethoxybenzyl analog, 25B-NBOMe, and $2 \mathrm{C}-\mathrm{N}-\mathrm{NBOMe}$, identified in illegal products. Forensic Toxicol 32:105-115

45. Angerer V, Mogler L, Steitz J-P, Bisel P, Hess C, Schoeder CT, Müller CE, Huppertz LM, Westphal F, Schäper J, Auwärter V (2017) Structural characterization and pharmacological evaluation of the new synthetic cannabinoid CUMYL-PEGACLONE. Drug Test Anal. https://doi.org/10.1002/dta.2237

46. Rinaldi-Carmona M, Barth F, Millan J, Derocq JM, Casellas P, Congy C, Oustric D, Sarran M, Bouaboula M, Calandra B, Portier M, Shire D, Brelière JC, Le Fur GL (1998) SR 144528, the first potent and selective antagonist of the CB2 cannabinoid receptor. J Pharmacol Exp Ther 284:644-650

47. Ross RA, Brockie HC, Stevenson LA, Murphy VL, Templeton F, Makriyannis A, Pertwee RG (1999) Agonist-inverse agonist characterization at $\mathrm{CB}_{1}$ and $\mathrm{CB}_{2}$ cannabinoid receptors of $\mathrm{L} 759633$, L759656, and AM630. Br J Pharmacol 126:665-672

48. Shao Z, Yin J, Chapman K, Grzemska M, Clark L, Wang J, Rosenbaum DM (2016) High-resolution crystal structure of the human $\mathrm{CB}_{1}$ cannabinoid receptor. Nature 540:602-606

49. Hua T, Vemuri K, Pu M, Qu L, Han GW, Wu Y, Zhao S, Shui W, Li S, Korde A, Laprairie RB, Stahl EL, Ho J-H, Zvonok N, Zhou
H, Kufareva I, Wu B, Zhao Q, Hanson MA, Bohn LM, Makriyannis A, Stevens RC, Liu Z-J (2016) Crystal structure of the human cannabinoid receptor $\mathrm{CB}_{1}$. Cell 167:750-762

50. Adams AJ, Banister SD, Irizarry L, Trecki J, Schwartz M, Gerona R (2017) "Zombie" outbreak caused by the synthetic cannabinoid AMB-FUBINACA in New York. N Engl J Med 376:235-242

51. Longworth M, Banister SD, Boyd R, Kevin RC, Connor M, McGregor IS, Kassiou M (2017) Pharmacology of cumyl-carboxamide synthetic cannabinoid new psychoactive substances (NPS) CUMYL-BICA, CUMYL-PICA, CUMYL-5F-PICA, CUMYL-5F-PINACA, and their analogues. ACS Chem Neurosci 8:2159-2167

52. Rempel V, Volz N, Hinz S, Karcz T, Meliciani I, Nieger M, Wenzel W, Bräse S, Müller CE (2012) 7-Alkyl-3-benzylcoumarins: a versatile scaffold for the development of potent and selective cannabinoid receptor agonists and antagonists. J Med Chem 55:7967-7977

53. Rempel V, Fuchs A, Hinz S, Karcz T, Lehr M, Koetter U, Müller CE (2013) Magnolia extract, magnolol, and metabolites: activation of cannabinoid $\mathrm{CB}_{2}$ receptors and blockade of the related GPR55. ACS Med Chem Lett 4:41-45 